\title{
Organic and Biodynamic Viticulture Affect Biodiversity and Properties of Vine and Wine: A Systematic Quantitative Review
}

\author{
Johanna Döring, ${ }^{1 *}$ Cassandra Collins, ${ }^{2}$ Matthias Frisch, ${ }^{3}$ and Randolf Kauer ${ }^{1}$
}

\begin{abstract}
Demand for organically grown crops has increased exponentially in the last few decades. Particularly in the wine sector, organic and biodynamic management systems are gaining more and more importance, with some of the most prestigious wineries converting to organic or biodynamic viticulture. The purpose of this study was to review evidence comparing effects of conventional, organic, and biodynamic viticulture on soil properties, biodiversity, vine growth and yield, disease incidence, grape composition, sensory characteristics, and wine quality. Only studies with representative field replicates or studies with a representative number of samples were included. Soil nutrient cycling was enhanced under organic viticulture, especially after conversion was completed. Cover crop mixtures used, compost application, and the absence of herbicides might be factors that account for higher biological activity in organically and biodynamically managed soils. Seventeen out of 24 studies observed a clear increase in biodiversity under organic viticulture on different trophic levels. Plant protection regime and cover crop mixtures mainly determine higher biodiversity in organic and biodynamic viticulture. Organic and biodynamic treatments showed $21 \%$ lower growth and $18 \%$ lower yield compared to conventional viticulture. The decrease of growth and yield under organic and biodynamic viticulture was not correlated to the growth or yield level under conventional viticulture. A decrease in soil moisture content and physiological performance (assimilation rate, transpiration rate, and stomatal conductance) under organic and biodynamic viticulture is likely to be responsible for the lower growth and yield in the respective management systems. Juice total soluble solids concentration did not differ among the different management systems. No overall differences in berry composition or juice and wine quality among management systems could be observed. By describing different hypotheses concerning the effects of organic and biodynamic viticulture, this review and meta-analysis provides helpful guidance for defining further research in organic agriculture on perennial, but also on annual, crops.
\end{abstract}

Key words: biodiversity, cover crop, crop level, floor management, grape composition, vegetative growth, wine composition

The production of organically grown crops has increased exponentially in the last few decades based on consumer demands for healthy food as well as environmentally friendly farming practices (Yiridoe et al. 2005). Current agricultural and environmental policies are reacting to these demands with initiatives limiting the use of synthetic pesticides, thus promoting organic farming (Vidal and Kelly 2013, Wysling 2015,

\footnotetext{
${ }^{1}$ Department of General and Organic Viticulture, Hochschule Geisenheim University, Geisenheim, Germany; ${ }^{2}$ School of Agriculture, Food and Wine, University of Adelaide, Waite Research Institute, Adelaide, Australia; and ${ }^{3}$ Institute of Agronomy and Plant Breeding II, Justus-Liebig-University Gießen, Germany.

*Corresponding author (johanna.doering@hs-gm.de; tel: +49 6722502 164) Acknowledgments: The authors would like to thank M. Sc. Matthias Friedel for helpful revision and proof reading of the manuscript. This review did not receive any specific grant from funding agencies in the public, commercial, or not-for-profit sectors. No conflict of interest exists and authors declare the absence of any interest to disclose.

Supplemental data is freely available with the online version of this article at www.ajevonline.org.

Manuscript submitted May 2018, revised Nov 2018, accepted Jan 2019

Copyright ( $\odot 2019$ by the American Society for Enology and Viticulture. All rights reserved.

By downloading and/or receiving this article, you agree to the Disclaimer of Warranties and Liability. The full statement of the Disclaimers is available at http://www.ajevonline.org/content/proprietary-rights-notice-ajev-online. If you do not agree to the Disclaimers, do not download and/or accept this article. doi: 10.5344/ajev.2019.18047
}

Kucera 2017). The controversial debate on the ban of glyphosate, the main ingredient of Monsanto's best-selling herbicide "Roundup," in the European Union (EU) has lately made organic farming the center of attention again (Neslen 2017).

The start of organic agriculture that developed almost independently in the German- and English-speaking world dates back to the beginning of the last century. The first movements toward organic farming were developed from a reaction to ecological and soil-related issues, but also to economic and social problems that occurred during the two world wars. Acidification of soils, loss of soil structure, soil fatigue, decrease of seed and food quality, and an increase of plant and animal diseases were attributed to the chemical-technical intensification of agriculture (Vogt 2000). In addition, yield levels in Germany decreased drastically in the 1920s in comparison to the years before World War I, even though the use of mineral fertilizers increased. The early movements toward organic agriculture focused on improved soil fertility while reducing the use of mineral fertilizers, and aimed to create a more sustainable form of agriculture while still producing high quality crops. The different forms of organic agriculture have evolved with time and now incorporate knowledge about biologically stabilized soil structure, rhizosphere dynamics, and systems ecology (Vogt 2000, 2007). Research on the respective management systems started mainly after World War II with the establishment of some long-term field trials 
comparing different agricultural management systems (Stinner 2007). In viticulture, organic and biodynamic management approaches were initially applied in the late 1960s, with research on organic viticulture starting soon after (Danner 1985).

Land used for organic agriculture increased from 11 million ha in 1999 to 43.7 million ha in 2014, which is $~ 1 \%$ of global agricultural land. At the same time, the organic market size increased from US $\$ 15.2$ billion in 1999 to $\$ 80$ billion in 2014 (Lernoud and Willer 2016). Compared to total agriculture, perennial cropland has a much higher share in organic management (Lernoud and Willer 2016). In viticulture, 316,000 ha of grapes are grown organically, which is a $4.5 \%$ share of the global grapegrowing area. Most of this organic grapegrowing area is located in Europe (266,000 ha). The three countries with the largest organic grapegrowing area are Spain, Italy, and France (Lernoud and Willer 2016). Worldwide, 11,200 ha of vineyards for wine production are managed according to biodynamic principles or are in conversion to biodynamic viticulture (Castellini et al. 2017). The biggest international biodynamic association is Demeter. Particularly in the wine sector, organic and biodynamic management practices are gaining more importance, with some of the most prestigious wineries converting to organic or biodynamic viticulture (Reeve et al. 2005).

The United Nations' Food and Agriculture Organization (FAO) defines organic farming as follows: "Organic agriculture is a holistic production management system which promotes and enhances agroecosystem health, including biodiversity, biological cycles, and soil biological activity. It emphasizes the use of management practices in preference to the use of off-farm inputs... This is accomplished by using, where possible, agronomic, biological, and mechanical methods, as opposed to using synthetic materials, to fulfill any specific function within the system" (FAO 1999).

In the EU, several regulations exist to control organic farming (Regulation (EC) No. 834/2007, Regulation (EC) No. 889/2008). In Appendix II of Regulation (EC) No. 889/2008, there is a list of substances allowed in organic farming, and thus, organic viticulture. Any substance not on the list is forbidden. Furthermore, there is a regulation in the EU (Regulation (EU) No. 203/12) outlining detailed rules on organic winemaking. There are also specific national rules, for example, the restriction of copper $(\mathrm{Cu})$ use in German viticulture to $3 \mathrm{~kg} /$ ha/yr (BVL, accessed 15 April 2019; https://www.bvl.bund. de/DE/04_Pflanzenschutzmittel/01_Aufgaben/02_ZulassungPSM/01_ZugelPSM/psm_ZugelPSM_node.html), and several organic or biodynamic associations impose stricter rules than the EU standards (e.g., ECOVIN association in Germany imposes a maximum nitrogen $(\mathrm{N})$ input of $150 \mathrm{~kg} / \mathrm{ha} / 3 \mathrm{yrs}$ and allows growers to plough the soil within rows without sowing cover crop for a maximum three months during summer).

In the United States (US), the organic regulations by the US Department of Agriculture (USDA) control organic farming (USDA Organic Regulations; https://www.ams.usda.gov/rulesregulations/organic). The National Organic Program (NOP) develops rules and regulations for production, handling, labeling, and enforcement of organic products (USDA Organic Regulations). In contrast to EU standards, there is a National
List of Allowed and Prohibited Substances in the US (USDA National List; https://www.ams.usda.gov/rules-regulations/organic/national-list). Beyond that, various national and regional organic farming associations exist in the US.

In Australia, the biosecurity section of the Department of Agriculture, formerly the Australian Quarantine and Inspection Service of the Department of Agriculture, Fisheries, and Forestry of the Australian Government (AQIS), is responsible for the accreditation of the national certifying bodies according to the National Standard for Organic and Bio-Dynamic Produce (OISCC; http://www.agriculture.gov.au/SiteCollectionDocuments/aqis/exporting/food/organic/national-standardedition-3-7.pdf). Appendices of this national standard contain lists of permitted materials in organic and biodynamic farming, as well as the criteria to evaluate inclusion of inputs and additives in this standard (Organic Industry Standards and Certification Committee 2015). As of 2015, there were seven approved certifying organizations in Australia. Besides these national control bodies, there are several associations, such as Biodynamic Agriculture Australia and Demeter, that set stricter rules than does the national legislation.

There is a transition period of three years in the US, EU, and Australia for becoming a certified organic or biodynamic producer. The implementation of regulations concerning organic vineyard management is described by Provost and Pedneault (2016).

Biodynamic farming abides by the same regulations as organic farming. It is a holistic agricultural system based on respect for the spiritual dimension of the living and inorganic environment (Vogt 2007). It was founded in 1924 by Rudolf Steiner and was one of the first movements toward organic agriculture (Steiner 2005). It should ideally be practiced on mixed farms, including crops and livestock, to meet the requirements of the farm as an organism as identified by Steiner in his agricultural course (Steiner 2005). The application of specific biodynamic preparations is one key element of this management system (Leiber et al. 2006), and is one essential difference in comparison to organic farming. These substances are said to stimulate soil nutrient cycling and promote photosynthetic activity of the crops and compost transformation (Masson and Masson 2013). The following biodynamic preparations are usually applied in biodynamic agriculture: horn manure and horn silica (Table 1) are diluted in water in very small quantities, stirred for one hour, and then applied to soil or plants, respectively (Masson and Masson 2013). The compost preparations (Table 1) are applied to a compost and are said to facilitate the transformation process into decay products (Masson and Masson 2013). Each of the preparations is put into compost in small quantities and the valerian preparation is sprayed over the compost heap (Masson and Masson 2013).

The aim of this meta-analysis is to summarize the outcomes of scientific trials performed on organic and biodynamic viticulture worldwide, and hence to characterize the effects of the respective management systems. This review addresses the question of whether conventionally, organically, and biodynamically managed vineyards differ in regards to 
soil properties, biodiversity, vine growth and yield, disease incidence, grape composition, wine quality, sensory characteristics, and production costs. Qualitative results showing the overall effects of organic and biodynamic viticulture and quantitative results displayed as regression analyses of available data sets are presented. By describing and quantifying the effects of the respective viticultural management systems, this review provides decision support for producers, consumers, and researchers. In addition, new findings concerning the reasons for the effects of organic and biodynamic management in viticulture are described. Different hypotheses for explaining the observed phenomena are presented. Therefore, this review and meta-analysis also provides helpful guidance for defining future areas of research.

\section{Published Data Sourcing and Selection}

Literature searches of peer-reviewed published literature were conducted to find studies investigating organic and/ or biodynamic viticulture. The following search terms were used in different combinations in the ISI-Web of Science and PubMed databases: organic/viticulture, biodynamic/viticulture, biodynamic/agriculture/grapes (last searched 25 Aug 2017).

Only field trials that used replicates of management treatments with representative plots or studies that used a representative number of samples were included in the review in order to avoid bias in individual studies. Data from non-peerreviewed sources such as conference proceedings, master's theses, or doctoral dissertations were also included in this study if they met the criteria mentioned above. In Germany and Austria, some long-term studies were conducted between 1980 and 2015, whose results were published as doctoral theses in German. These findings were translated and included. In Australia, a long-term trial was conducted between 2009 and 2014 whose results were partially published as honors and master's theses, and results were included here. Furthermore, unpublished data from the Australian study and from a longterm trial in Germany were provided by the authors and were included in the review and in the meta-analysis.

This led to a total number of 84 studies included in the quantitative review, of which 64 were peer-reviewed and 20 were non-peer-reviewed.

Seventeen studies that met the criteria mentioned above and whose data sets were available were included in the quantitative meta-analysis. Data were extracted manually from the different studies. If different forms of conventional viticulture were included in the studies, low-input conventional plots were chosen for meta-analysis. If compost was applied to the different plots, as was the case in the Australian long-term trial, means per treatment and year were calculated for plots with and without compost application. These treatment means were included in the meta-analysis. For the study by Linder et al. (2006) and by Wheeler and Crisp (2011), means per treatment over eight- and five-year periods, respectively, were available and were included. Characteristics of the studies included in the meta-analysis and meta-regressions are presented in Supplemental Table 1.

\section{Data Analysis}

Linear meta-regression analyses were performed to evaluate the quality of the correlations of several parameters (growth, yield, and total soluble solids [TSS] in juice) between conventionally and organically or biodynamically managed vineyards. By meta-regression analyses, the following question was addressed: What is the magnitude of the effect of organic and biodynamic management on vine growth (expressed as pruning weight), vine yields, and TSS in juice?

To assess whether conventional and organic/biodynamic viticulture differ in vine growth, vine yield, and TSS in juice, and whether the observed effects are consistent across all environments, analysis of variance (ANOVA) and Tukey's test (post-hoc test) were performed. The factors were treatment (conventional or organic, including biodynamic) and location of the study (United States, Europe, or Australia), and interactions between treatment and location were assessed. All statistics were carried out using the statistical software R (Ihaka and Gentleman 1996). For meta-regression analysis, as well as for ANOVA and Tukey's test means per treatment, year and variety were calculated to avoid bias among studies due to differing numbers of plots or vineyards.

For all studies considered in the meta-analysis and metaregressions, effects and variance were estimated (Supplemental Figures 1 to 3). Studies are partially heterogenic (especially concerning the pruning weight), are limited in number, and publication bias cannot be excluded.

\section{Management Effects on Soil}

The improvement of soil fertility without any synthetic $\mathrm{N}$ fertilizers is a key principle of organic farming. The most important source of $\mathrm{N}$ as well as other nutrients in organic farming is the use of compost. It supplies the soil with organic

\begin{tabular}{lll}
\hline & Table 1 & Main ingredients of the biodynamic preparations 500 to 507 (adapted from Reeve et al. 2005). \\
\hline Preparation & Main ingredient & Use \\
\hline Horn manure (500) & Cow (Bos taurus) manure & Field spray \\
Horn silica (501) & Finely ground quartz silica & Field spray \\
Yarrow (502) & Yarrow blossoms (Achillae millefoilium L.) & Compost \\
Chamomile (503) & Chamomile blossoms (Matricaria recutita L. or Matricaria chamomilla L.) & Compost \\
Stinging nettle (504) & Stinging nettle shoots and leaves (Urtica dioica L.) & Compost \\
Oak bark (505) & Oak bark (Quercus robur L.) & Compost \\
Dandelion (506) & Dandelion flowers (Taraxacum officinalis L.) & Compost \\
Valerian (507) & Valerian flower extract (Valeriana officinalis L.) &
\end{tabular}


$\mathrm{N}$, which has to be converted into inorganic $\mathrm{N}$ compounds to be taken up by the plants (Kauer 1994, Vogt 2007). Therefore, the stimulation of soil nutrient cycling plays a major role in organic farming as well as in organic viticulture to supply the plants with inorganic nutrients. The biological activity of the soil and the feeding activity of soil organisms are reported to increase under organic and biodynamic viticulture in comparison to conventional management (Gehlen et al. 1988, Reinecke et al. 2008, Okur et al. 2009, Freitas et al. 2011) (Table 2). The contents of organic carbon (C) and total N, phosphorus (P), and sulfur (S) did not differ among treatments (Wheeler 2006, Probst et al. 2008, Collins et al. 2015b). In contrast, $P$ contents in the soil were reported to rapidly decrease after conversion in a long-term field trial in southern France. After seven years of conversion, authors observed a gradual increase of available $P$ contents under organic management (Coll et al. 2011). Biodynamic and organic vineyards show a higher cumulative soil respiration, a higher content of microbial biomass $\mathrm{C}$, and a higher ratio of microbial biomass $\mathrm{C}$ to organic $\mathrm{C}$, especially after conversion (Gehlen et al. 1988, Probst et al. 2008, Okur et al. 2009, Coll et al. 2011, Freitas et al. 2011, Collins et al. 2015b). In one study conducted in southern France, soil organic matter and potassium $(\mathrm{K})$ content were increased under organic viticulture (Coll et al. 2011). Two reasons for the increased contents of $\mathrm{P}$ and $\mathrm{K}$ in the soil under organic viticulture could be the increased microbial activity and the increased microbial biomass (Coll et al. 2011). In addition, organic and biodynamic treatments show lower $q \mathrm{CO}_{2}$ values (Probst et al. 2008, Freitas et al. 2011). Low $q \mathrm{CO}_{2}$ values indicate high microbial substrate-use efficiency (Probst et al. 2008). This is in accordance with the results of Mäder et al. (2002), who showed that higher microbial substrate-use efficiency in combination with a higher availability of soil organic matter to soil microorganisms is a characteristic result of organic farming. Yet indicators of microbial activity in the soil are strongly dependent on the vineyard location and its management. The positive effects of organic and biodynamic vineyard management on soil microbial properties are reported to increase together with the time-span since conversion (Probst et al. 2008, Coll et al. 2011). Mineralized N content in the topsoil layer did not differ among organic, biodynamic, and integrated viticulture in a field trial in Germany in the first three years of conversion (Meißner 2015). Integrated farming is an approach that promotes sustainable farming by using all possible tools and techniques to reduce input of chemicals. Polluting inputs are minimized and resources are used sustainably (Ente Nazionale Italiano di Unificazione 2009). In the same trial where results of Meißner (2015) were obtained, mineralized $\mathrm{N}$ content in the topsoil layer was reported to increase under organic and biodynamic management after the first four years of conversion (Döring et al. 2015). This implies that stimulation of soil nutrient cycling by compost application, the implementation of cover crop mixtures with a wide range of species, including legumes, and denial of mineral fertilizers, as practiced in the organic and biodynamic treatments, takes some years to make an impact on
$\mathrm{N}$ levels and on microbial activity in the soil. This again is in accordance with other findings concerning soil microbial properties under organic management (Coll et al. 2011). As mentioned above, microbial biomass $\mathrm{C}$ also increased under organic and biodynamic viticulture after conversion in a long-term field trial in Australia (Collins et al. 2015a). Soil quality such as microbial efficiency and mineralized $\mathrm{N}$ content in the soil did not differ between organic and biodynamic treatments (Reeve et al. 2005, Döring et al. 2015, Meißner 2015) (Table 3).

Increased soil compaction under organic viticulture was reported in a long-term trial in southern France (Coll et al. 2011). This might be due to a higher frequency of plant protection applications under organic farming.

$\mathrm{Cu}$ products are among the oldest plant protection agents and represent an important part of the plant protection strategy against downy mildew (caused by Plasmopara viticola) in organic viticulture. However, $\mathrm{Cu}$ is accumulated in the soil, and high $\mathrm{Cu}$ content in vineyard soils is mainly due to anthropogenic inputs in past decades (Probst et al. 2008, Strumpf et al. 2009). $\mathrm{Cu}$ inputs from 1890 to 1940 were typically up to $50 \mathrm{~kg} / \mathrm{ha} / \mathrm{yr}$ in viticulture (Strumpf et al. 2011). In long established winegrowing regions with long-term $\mathrm{Cu}$ application, $\mathrm{Cu}$ levels in the soil are higher compared to areas where viticulture was developed within the last three to five decades (Strumpf et al. 2009). There is no direct correlation between $\mathrm{Cu}$ content in the soil and its plant availability (Steindl et al. 2011). $\mathrm{Cu}$ content in grapes is low even if $\mathrm{Cu}$ content in the soil is high (Strumpf et al. 2009). Cu levels in viticultural soils have impact on total $\mathrm{C}$, enzyme activities, and biodiversity, especially on earthworm abundance in the soil (Paoletti et al. 1998, Mackie et al. 2013). Although amounts of $\mathrm{Cu}$ used for plant protection in organic viticulture are higher compared to the amounts usually used in conventional viticulture, organically managed vineyard soils in France, Croatia, and Germany did not have a higher $\mathrm{Cu}$ content compared to their conventional counterparts (Probst et al. 2008, Coll et al. 2011, Strumpf et al. 2011, Radić et al. 2014). Beni and Rossi (2009), in contrast, observed higher total $\mathrm{Cu}$ contents under organic farming after nine years in Italy. In an Italian study on organic viticulture, $\mathrm{Cu}$ amounts in soils, on berries, and in wines were below the maximum residue levels (Provenzano et al. 2010). Since vineyard soils under conventional, organic, or biodynamic management did not show differences in $\mathrm{Cu}$ levels in most of the studies, there were no negative implications for earthworms in the soil (Strumpf et al. 2011).

\section{Management Effects on Biodiversity}

Biodiversity in agroecosystems provides multiple ecological services beyond food production that lead to increasing internal regulation of food production (Altieri 1999). Results concerning biodiversity in annual crops and grasslands support the hypothesis that organic farming enhances biodiversity. There is evidence that organic agricultural methods increase species richness and abundance compared to conventional farming systems (Bengtsson et al. 2005, Hole et al. 2005). On average, species richness was $30 \%$ higher, 
Table 2 Effects of organic viticulture in comparison to conventional viticulture grouped by different fields of interest.

\begin{tabular}{|c|c|c|c|}
\hline $\begin{array}{l}\text { Field of interest/ } \\
\text { parameters }\end{array}$ & $\begin{array}{l}\text { Effect compared } \\
\text { to integrated/ } \\
\text { conventional } \\
\text { management }\end{array}$ & $\begin{array}{c}\text { Management } \\
\text { system }\end{array}$ & References \\
\hline
\end{tabular}

\section{Soil}

Biological activity, feeding activity of soil organisms, Increase Org Coll et al. 2011, Freitas et al. 2011, Gehen 1988,

soil organic matter, total $\mathrm{K}$

Soil organic C content, total N, P, S, microbial biomass $\quad$ No difference

Okur et al. 2009, Reinecke et al. 2008

C during conversion

\begin{tabular}{lccl}
\hline $\begin{array}{l}\text { Microbial biomass } \mathrm{C}, \mathrm{C}_{\mathrm{mic}} / \mathrm{C}_{\text {org }} \text {, soil respiration after } \\
\text { conversion }\end{array}$ & Increase & Org biodyn & $\begin{array}{l}\text { Collins et al. 2015b, Freitas et al. 2011, Gehlen 1988, } \\
\text { Okur et al. 2009, Probst et al. 2008 }\end{array}$ \\
\hline Soil compaction & Increase & Org & Coll et al. 2011 \\
\hline Metabolic quotient $q \mathrm{CO}_{2}$ & Decrease & Org biodyn & Freitas et al. 2011, Probst et al. 2008 \\
\hline Mineralized N during conversion & No difference & Org biodyn & Coll et al. 2011, Meißner 2015 \\
\hline Mineralized N after conversion & Increase & Org biodyn & Döring et al. 2015 \\
\hline Cu content in soils & No difference & Org biodyn & $\begin{array}{l}\text { Coll et al. 2011, Probst et al. 2008, Radic et al. 2014, } \\
\text { Strumpf et al. 2011 }\end{array}$ \\
\hline Cu content in soils & Increase & Org & Beni and Rossi 2009 \\
\hline Soil moisture & Decrease & Org biodyn & Collins et al. 2015b \\
\hline
\end{tabular}

\section{Biodiversity}

Arbuscular mycorrhizal fungi, bacterial biodiversity in
topsoil,fungal diversity on leaves, shoots, and grapes

Increase Org biodyn Bagheri et al. 2015, Freitas et al. 2011,

Hendgen et al. 2018, Morrison-Whittle et al. 2017, Radic et al. 2014, Schmid et al. 2011

species abundance in must

Fungal species richness in soil, epiphytic microbial communities on grapes, fungal community composition in harvested juice

Yeast abundance on grapes

Plant species richness, perennial plant species, earthworm abundance, nematode density, biodiversity and abundance of predatory mites, species richness of butterflies, biodiversity and abundance of arthropods, ladybird abundance, detritivore abundance, colembola abundance, spider biodiversity, feeding ecology of birds

Plant diversity and abundance, plant species composition, moth biodiversity, insect pollination, spider biodiversity and abundance, biodiversity and abundance of birds

Endogenic earthworm density and biomass, abundance of predatory mites, biodiversity of grasshoppers, biodiversity of ladybirds

No difference Org biodyn Bagheri et al. 2015, Hendgen et al. 2018, Kecskeméti et al. 2016, Morrison-Whittle et al. 2017

$\begin{array}{ccl}\text { Decrease } & \text { Biodyn } & \text { Guzzon et al. 2016 } \\ \text { Increase } & \text { Org biodyn } & \begin{array}{l}\text { Caprio et al. 2015, Caprio and Rolando 2017 } \\ \text { Coll et al. 2011, Collins et al. 2015b, } \\ \text { Fleury and Fleury 2016, Isaia et al. 2006, } \\ \text { Meißner 2015, Nascimbene et al. 2012, } \\ \text { Peverieri et al. 2009, Puig-Montserrat et al. } \\ \text { Wheeler 2006 }\end{array} \\ \text { No difference } & \text { Org } & \begin{array}{l}\text { Assandri et al. 2016, Brittain et al. 2010, } \\ \text { Bruggisser et al. 2010, Nascimbene et al. } \\ \text { Puig-Montserrat et al. 2017 }\end{array} \\ & & \begin{array}{l}\text { Bruggisser et al. 2010, Coll et al. 2011, } \\ \text { Fleury and Fleury 2016, Linder et al. 2006 }\end{array}\end{array}$

\section{Growth}

Ratio yield:pruning weight

No difference

Ratio leaf area:fruit weight

No difference

Org biodyn

Collins et al. $2015 b$

Pruning weight, shoot length, canopy density

Decrease

Org biodyn

Döring et al. 2015

Leaf area index (LAI)

No difference

Org biodyn

Collins et al. 2015b, Corvers 1994, Döring et al. 2015, Hofmann 1991, Kauer 1994, Malusà et al. 2004, Meißner 2015, Pike 2014

Leaf area index (LAI)

No difference

Org

Corvers 1994

Macronutrient supply in leaves (veraison), chlorophyll

Decrease

Org biodyn

Döring et al. 2015

content (full-bloom)

No difference Org biodyn

Nitrogen content in leaves (veraison)

Increase

Org biodyn

Collins et al. 2015b, Döring et al. 2015,

Linder et al. 2006, Meißner 2015

Nitrogen content in leaves, nutrient supply

Decrease

Döring et al. 2015

Chlorophyll content (veraison), $\mathrm{Mg}$ and $\mathrm{P}$ contents in

Decrease

Org biodyn

Danner 1985, Malusà et al. 2004

leaves or petioles

Physiological performance (A, E, gs)

Decrease

Org biodyn

Collins et al. 2015b, Döring et al. 2015, Meißner 2015

Predawn water potential $\Psi_{\mathrm{pd}}$

Stem water potential before harvest

Decrease

Org biodyn

Döring et al. 2015

No difference

Biodyn

Döring et al. 2015

Yield

Decrease Org biodyn

No difference
Org 
Table 2 (continued) Effects of organic viticulture in comparison to conventional viticulture grouped by different fields of interest.

\begin{tabular}{|c|c|c|c|}
\hline $\begin{array}{l}\text { Field of interest/ } \\
\text { parameters }\end{array}$ & $\begin{array}{l}\text { Effect compared } \\
\text { to integrated/ } \\
\text { conventional } \\
\text { management }\end{array}$ & $\begin{array}{l}\text { Management } \\
\text { system }\end{array}$ & References \\
\hline \multicolumn{4}{|l|}{ Yield (continued) } \\
\hline Berry weight & No difference & Org & Corvers 1994, Pool and Robinson 1995 \\
\hline Berry weight, compactness of bunches & Decrease & Org biodyn & $\begin{array}{l}\text { Collins et al. 2015b, Döring et al. 2015, Linder et al. } \\
\text { 2006, Meißner 2015, Pool and Robinson } 1995\end{array}$ \\
\hline \multirow[t]{2}{*}{ Number berries per bunch, average bunch weight } & Decrease & Org biodyn & Corvers 1994, Collins et al. 2015b, Döring et al. 2015 \\
\hline & No difference & Org & Pool and Robinson 1995 \\
\hline \multicolumn{4}{|l|}{ Disease incidence } \\
\hline \multirow[t]{2}{*}{ Disease incidence Plasmopara viticola } & No difference & Org biodyn & Danner 1985, Pike 2014 \\
\hline & Increase & Org biodyn & Döring et al. 2015 \\
\hline Disease incidence Erysiphe necator & Increase & Org & Linder et al. 2006 \\
\hline \multirow[t]{2}{*}{ Disease incidence Botrytis cinerea } & Increase & Org biodyn & Danner 1985, Döring et al. 2015 \\
\hline & No difference & Org biodyn & Danner 1985, Meißner 2015, Pike 2014 \\
\hline $\begin{array}{l}\text { Disease incidence sour rot, root necrosis } \\
\text { (fungal pathogens) }\end{array}$ & Decrease & Org biodyn & Döring et al. 2015, Lotter et al. 1999, Meißner 2015 \\
\hline \multicolumn{4}{|l|}{ Winegrape quality } \\
\hline Berry composition & No difference & Org biodyn & $\begin{array}{l}\text { Collins et al. 2015a, Collins et al. 2015b, Danner 1985, } \\
\text { Döring et al. 2015, Henick-Kling 1995, Hofmann 1991, } \\
\text { Kauer 1994, Linder et al. 2006, Malusà et al. 2004, } \\
\text { Tassoni et al. 2013, Tassoni et al. 2014, Wheeler } 2006\end{array}$ \\
\hline Fe and $\mathrm{Zn}$ in berries & Increase & Org & Coffey 2010 \\
\hline Volatile acidity and malic acid & Increase & Org & Beni and Rossi 2009 \\
\hline Juice acidity, citric acid in wines & Decrease & Org biodyn & Corvers 1994, Meißner 2015, Tobolková et al. 2014 \\
\hline Juice and wine quality & No difference & Org biodyn & $\begin{array}{l}\text { Danner 1985, Dupin et al. } 2000 \text {, Granato et al. 2015b, } \\
\text { Granato et al. 2015c, Granato et al. 2016, } \\
\text { Henick-Kling 1995, Kauer 1994, Meißner } 2015\end{array}$ \\
\hline Juice quality (by image forming methods) & Increase & Org biodyn & Fritz et al. 2017 \\
\hline \multirow[t]{2}{*}{ Yeast available nitrogen } & Increase & Biodyn & Döring et al. 2015 \\
\hline & No difference & Org biodyn & Collins et al. 2015b, Meißner 2015 \\
\hline $\begin{array}{l}\text { Anthocyanin and flavonoid content in berry skin, } \\
\text { putrescine (biogenic amine) in wines }\end{array}$ & Increase & Org & Malusà et al. 2004, Yildirim et al. 2007 \\
\hline $\begin{array}{l}\text { Polyphenol content, antioxidant potential (grapes, juice, } \\
\text { and wine), phenolic acids, enzyme polyphenol oxidase, } \\
\text { trans-resveratrol }\end{array}$ & Increase & Org biodyn & $\begin{array}{l}\text { Buchner et al. 2014, Dani et al. 2007, Granato et al. } \\
\text { 2015a, Micelli et al. 2003, Malusà et al. 2004, } \\
\text { Nuñez-Delicado et al. 2005, Otreba et al. 2011, } \\
\text { Rodrigues et al. 2012, Tinttunen and Lehtonen 2001, } \\
\text { Vrček et al. 2011, Yildirim et al. } 2004\end{array}$ \\
\hline $\begin{array}{l}\text { Alcohol content, total anthocynanins, polyphenol profile } \\
\text { grapes and wines, carotenoids, color density in wine, } \\
\text { trans-resveratrol, } p \text {-coumaric acid, antioxidant activity, } \\
\text { biogenic amines }\end{array}$ & No difference & Org biodyn & $\begin{array}{l}\text { Bunea et al. 2012, Collins et al. 2015a, Collins et al. } \\
2015 \mathrm{~b} \text {, Garaguso and Nardini } 2015 \text {, Lante et al. 2004, } \\
\text { Mulero et al. } 2009 \text {, Mulero et al. 2010, } \\
\text { Tassoni et al. } 2013\end{array}$ \\
\hline $\begin{array}{l}\text { Polyphenol content, antioxidant activity in wine, Cu and } \\
\text { Fe in wines, ascorbic acid equivalents, ferric-reducing } \\
\text { power }\end{array}$ & Decrease & Org & $\begin{array}{l}\text { Beni and Rossi 2009, Tobolková et al. 2014, } \\
\text { Yildirim et al. } 2004\end{array}$ \\
\hline
\end{tabular}

\section{Sensory characteristics}

Berry sensory analysis - pulp juiciness

Increase Org Coffey 2010

Wine sensory characteristics

No difference

Org biodyn

Danner 1985, Dupin et al. 2000, Kauer 1994, Meißner 2015

Sensory attributes "floral, fruity, vegetal, complex, skunky, astringent"

Decrease Org biodyn Beni and Rossi 2009, Dupin et al. 2000,

Sensory attributes "balance, full-bodied, minerality, length"

Sensory attributes "rich, textual, complex, vibrant, spicy"

Sensorial preference of tasting panel (ranking)

Increase Biodyn Beni and Rossi 2009, Meißner 2015

\section{Costs and efficiency}

Production costs and operational costs, productive efficiency

Increase

Org Biodyn Collins et al. 2015

Increase

Biodyn

Collins et al. 2015

Increase Biodyn

Beni and Rossi 2009, Henick-Kling 1995, Meißner 2015 
and organisms were $50 \%$ more abundant in organic farming systems, compared to conventional management in annual crops (Bengtsson et al. 2005). Still, effects differed between organism groups and landscapes, and benefits for biodiversity have not always been found. Birds, predatory insects, soil organisms, and plants showed enhanced biodiversity under organic farming, while nonpredatory insects and pests did not (Bengtsson et al. 2005, Hole et al. 2005). It is controversially discussed whether an organic whole-farm approach provides more benefits for biodiversity than the establishment of small habitats within intensively used agricultural land (Hole et al. 2005). Further research is needed to assess the long-term effects of organic agriculture on biodiversity. Perennial cropping systems such as vineyards could be a good model for long-term studies on biodiversity since their lifespan usually comprises at least a few decades, and they often provide habitats for rare and endangered species because of their climatic peculiarities (Bruggisser et al. 2010). Thus, biodiversity in perennial systems such as vineyards can generally be very high (Isaia et al. 2006, Peverieri et al. 2009). Nevertheless, the effects of organic management on biodiversity in perennial crops have not been reviewed.

Table 3 Effects of biodynamic viticulture in comparison to organic viticulture.

\begin{tabular}{|c|c|c|c|}
\hline $\begin{array}{l}\text { Field of interest/ } \\
\text { parameters }\end{array}$ & $\begin{array}{l}\text { Effect compared } \\
\text { to organic } \\
\text { management }\end{array}$ & $\begin{array}{l}\text { Management } \\
\text { system }\end{array}$ & References \\
\hline \multicolumn{4}{|l|}{ Soil and biodiversity } \\
\hline $\begin{array}{l}\text { Soil quality, mineralized } \mathrm{N} \text {, microbial efficiency in soil, } \\
\text { epiphytic microbial communities, arthropods }\end{array}$ & No difference & Biodyn & $\begin{array}{l}\text { Döring et al. 2015, Kecskeméti et al. 2016, } \\
\text { Reeve et al. 2005, Meißner } 2015\end{array}$ \\
\hline Earthworm abundance & Increase & Biodyn & Meißner 2015 \\
\hline \multicolumn{4}{|l|}{ Growth } \\
\hline \multirow[t]{2}{*}{ Ratio yield:pruning weight } & Decrease & Biodyn & Reeve et al. 2005 \\
\hline & No difference & Biodyn & Collins et al. 2015b \\
\hline $\begin{array}{l}\text { Pruning weight, LAI }{ }^{\mathrm{a}} \text {, leaf-area-to-fruit-weight- } \\
\text { ratio, macronutrients in leaves, chlorophyll content, } \\
\text { physiological performance }\end{array}$ & No difference & Biodyn & $\begin{array}{l}\text { Döring et al. } 2015 \text {, Meißner et al. } 2015 \text {, } \\
\text { Reeve et al. } 2005\end{array}$ \\
\hline \multirow[t]{2}{*}{ Stomatal conductance } & No difference & Biodyn & Döring et al. 2015 \\
\hline & Decrease & Biodyn & Botelho et al. 2015 \\
\hline Leaf enzymatic activity, intrinsic WUE & Increase & Biodyn & Botelho et al. 2015 \\
\hline Predawn water potential $\Psi_{p d}$ & Decrease & Biodyn & Botelho et al. 2015, Döring et al. 2015 \\
\hline \multicolumn{4}{|l|}{ Yield } \\
\hline & No difference & Biodyn & $\begin{array}{l}\text { Botelho et al. 2015, Döring et al. 2015, Meißner 2015, } \\
\text { Reeve et al. } 2005\end{array}$ \\
\hline & Decrease & Biodyn & Danner 1985 \\
\hline $\begin{array}{l}\text { Clusters per vine, cluster weight, cluster compactness, } \\
\text { berry weight }\end{array}$ & No difference & Biodyn & Döring et al. 2015, Meißner 2015, Reeve et al. 2005 \\
\hline \multicolumn{4}{|l|}{ Disease incidence } \\
\hline Disease frequency Plasmopara viticola, Botrytis cinerea & No difference & Biodyn & Danner 1985, Döring et al. 2015, Pike 2014 \\
\hline Disease frequency $B$. cinerea & Decrease & Biodyn & Danner 1985 \\
\hline \multicolumn{4}{|l|}{ Winegrape quality } \\
\hline Grape composition and wine quality & No difference & Biodyn & $\begin{array}{l}\text { Danner 1985, Döring et al. 2015, Granato et al. 2015a, } \\
\text { 2015b, Laghi et al. 2014, Meißner 2015, Parpinello et al. } \\
\text { 2015, Partignani et al. 2017, Picone et al. 2016, Reeve } \\
\text { et al. 2005, Tassoni et al. 2013, } 2014\end{array}$ \\
\hline Juice quality (by image forming methods) & Increase & Biodyn & Fritz et al. 2017 \\
\hline $\begin{array}{l}\gamma \text {-Aminobutyric acid, amino acids, organic acids, total } \\
\text { phenols, total anthocyanins, trans-caffeic acid }\end{array}$ & Increase & Biodyn & Laghi et al. 2014, Picone et al. 2016, Reeve et al. 2005 \\
\hline $\begin{array}{l}\text { Juice acidity, sugars, alcohol content, phenolic } \\
\text { compounds, wine color, total polymeric pigments, } \\
\text { tannins, glutamine, coumaric acid, trans-caffeic acid }\end{array}$ & Decrease & Biodyn & $\begin{array}{l}\text { Laghi et al. 2014, Meissner 2015, Parpinello et al. 2015, } \\
\text { Picone et al. } 2016\end{array}$ \\
\hline \multicolumn{4}{|l|}{ Sensory characteristics } \\
\hline Wine sensory characteristics, sensorial preference & No difference & Biodyn & $\begin{array}{l}\text { Danner 1985, Martin and Rasmussen 2011, Parpinello } \\
\text { et al. 2015, Partignani et al. 2017, Ross et al. } 2009\end{array}$ \\
\hline Sensorial preference of tasting panel (ranking) & Increase & Biodyn & Meißner 2015 \\
\hline \multicolumn{4}{|l|}{ Costs } \\
\hline Production costs & Increase & Biodyn & Danner 1985, Delmas et al. 2008 \\
\hline Operational costs (undervine + canopy) & No difference & Biodyn & Santiago 2010 \\
\hline
\end{tabular}

aLAI, leaf area index; WUE, water use efficiency. 
One hypothesis claims that biodiversity under organic management of perennial crops declines compared to conventional management. According to the intermediate disturbance hypothesis (Grime 1973, Horn 1975, Connell 1978, Bruggisser et al. 2010), biodiversity is linked to the level of disturbance in agroecosystems (caused by agricultural practices such as ploughing or mulching) in a nonlinear way. At intermediate disturbance levels the highest biodiversity is found. Perennial cropping systems are characterized by a lower level of background disturbance in relation to annual cropping systems. It is hypothesized that in perennial cropping systems, a further increase in disturbance, as caused by organic management, leads to a decline of biodiversity in contrast to annual cropping systems, where an increase of the level of background disturbance leads to an increase in biodiversity (Bruggisser et al. 2010).

\section{Microbial Diversity in the Vineyard}

Abundance of arbuscular mycorrhizal fungi increased under organic management (Freitas et al. 2011, Radić et al. 2014). Fungal endophyte colonization of the roots of grapevines and associated weeds under organic management, species richness, diversity indices, and arbuscular mycorrhizal spore abundance were higher compared to conventional management (Radić et al. 2014). No difference in fungal species richness was assessed in soils of biodynamically and conventionally managed vineyards in New Zealand (MorrisonWhittle et al. 2017). In contrast, management systems differed in the types of species present and in the abundance of single species. These results are supported by Hendgen et al. (2018), who recently observed a fungal community shift under organic viticulture in the topsoil layer without affecting fungal species richness in a long-term field trial in Germany. Bacterial biodiversity was increased in topsoil under organic management compared to conventional viticulture, the latter using mineral fertilizers, herbicides, and synthetic fungicides (Hendgen et al. 2018).

Several different vineyards in different locations differing in management approaches (organic or integrated) were compared concerning fungal endophytic communities on grapevine stems using both cultivation-based and cultivationindependent methods. The fungal endophytic communities under organic management were different from the ones under integrated management (Pancher et al. 2012). Fungicides used in the respective management approaches may be the driving force in shaping fungal community composition. The level of tolerance of the fungi to the applied fungicides is unknown.

The application of organic fertilizers in organic viticulture might be another factor that potentially influences fungal community composition. Variability of fungal endophytic communities from farms applying integrated pest management is described as smaller compared to organic farms. Aureobasidium pullulans was ubiquitous on farms with integrated pest management (Pancher et al. 2012). In contrast, A. pullulans was found to be characteristic for organically managed vineyards (Schmid et al. 2011). In this latter study, organically and conventionally managed vineyards were compared concerning epiphytic and endophytic microbial communities on leaves, shoots, and grapes close to harvest in two subsequent years. Molecular analysis was performed by DNA extraction and fingerprinting. The conventional treatment showed highest abundance of Sporidiobolus pararoseus, whereas the organic treatment showed highest abundance of $A$. pullulans, as mentioned above. Schmid et al. (2011) explained A. pullulans presence in organic viticulture by its ability to metabolize inorganic $\mathrm{S}$ and absorb $\mathrm{Cu}$. On the other hand, it remains unclear why Pancher et al. (2012) found A. pullulans to be characteristic for integrated pest management. Fungal ITS copy number was higher in organic compared to conventional treatment samples, indicating a higher fungal diversity in organic viticulture. Antiphytopathogenic potential of fungal isolates is described as higher for organic management. No differences concerning bacterial community composition were described (Schmid et al. 2011). The composition of the epiphytic microbial community on ripening Riesling grapes was not different among management systems in a field trial comprising integrated, organic, and biodynamic management (Kecskeméti et al. 2016).

Fungal species richness in bark and on ripe fruit assessed by metagenomics was higher in biodynamic compared to conventional viticulture (Morrison-Whittle et al. 2017). In bark, species richness differed, but not types of species or abundance. Species richness describes the number of species present in a certain environment, while abundance describes the number of single individuals of the same species present in a certain environment. While species richness and species abundance might be the same in two different environments, the types of species can potentially differ from one environment to the other. On ripe fruit, types of species and abundance differed between management systems. Differences in abundance of the genera Columnosphaeria, Davidiella, Hanseniaspora, Chalara, and Trichothecium were detected.

The observed differences in fungal biodiversity and abundance did not lead to a different community composition in the harvested juice (Sauvignon blanc) of biodynamically and conventionally managed vineyards (Morrison-Whittle et al. 2017). This might be due to a rough change of the environmental conditions from grape berries to pressed juice. Many yeasts that are present on harvested grapes are not adapted to the environment as it occurs in grape juice with low $\mathrm{pH}$, lack of oxygen, and high sugar contents (Morrison-Whittle et al. 2017). Bagheri et al. (2015) assessed yeast population dynamics during spontaneous fermentation in Cabernet Sauvignon musts from biodynamic, integrated, and conventional management in South Africa. The farming systems differed in yeast community composition. The biodynamic vineyard had the highest culturable yeast diversity in both years of the study and the highest initial number of colony-forming units (cfu), indicating a higher species abundance. Candida parapsilosis and Saccharomyces cerevisiae were exclusively isolated from biodynamic musts at the start of fermentation. Cultivation-based assessment of the yeast community by Fourier transform infrared spectroscopy (FTIR), in contrast, showed a lower abundance of yeasts under biodynamic than conventional management (Guzzon et al. 2016). These 
different results concerning yeast abundance under biodynamic and conventional viticulture might be due to different isolation and cultivation techniques and/or environmental conditions and management.

There is evidence that diversity of the microbial community on grapes and vines is enhanced under organic viticulture, although no characteristic fungi or bacteria for organic management could be found. Different results concerning the microbial community composition in one vineyard over the years indicate that the community composition is highly dependent on climatic conditions of every single vintage (Bagheri et al. 2015, Guzzon et al. 2016). Results concerning single yeast strains, fungi, or bacteria seem to be influenced by climatic conditions, sampling date, specific pest management strategies, or isolation techniques. The plant protection strategy is likely to highly influence yeast and fungal community composition, since most of the agents used in organic and conventional viticulture are fungicides against downy and powdery mildew. Little is known about their impact on the different yeast strains and fungi on grapes and vines.

\section{Floral Biodiversity}

Bruggisser et al. (2010) investigated biodiversity in organic and conventional Swiss vineyards at different trophic levels. Plant diversity, abundance, and richness were not enhanced under organic viticulture compared to conventionally managed vineyards, and no species were found that exclusively occurred in organically managed sites. Nascimbene et al. (2012) detected higher plant species richness in organically managed vineyards and adjacent noncrop areas compared to conventional management within an intensively used agricultural landscape in northern Italy. The positive effect of organic viticulture on local plant species richness could be due to the intensively farmed and homogeneous landscape in northern Italy compared to Switzerland, meaning that the landscape context might modify the beneficial effects of organic viticulture on biodiversity (Brittain et al. 2010, Nascimbene et al. 2012). The use of herbicides in conventional viticulture might account for the observed differences; mechanical operations and mowing regime did not differ between management systems (Nascimbene et al. 2012). In both vineyards and grassland strips, organic viticulture promoted growth of perennial species (higher abundance) in contrast to conventional farming, indicating a negative impact of herbicide application on the establishment of perennial plant species (Nascimbene et al. 2012). A recent study conducted in northern Spain comparing conventionally and organically managed vineyards found organic plots to host a richer community of vascular plants (Puig-Montserrat et al. 2017). Vegetation species density was higher under organic farming. As in the previous study, the use of herbicides might account for the lower community richness under conventional viticulture (Puig-Montserrat et al. 2017).

\section{Earthworm Biodiversity}

Earthworm abundance increased under organic and biodynamic management compared to integrated viticulture (Collins et al. 2015b, Meißner 2015), and was even higher under biodynamic compared to organic viticulture in a replicated field trial in Germany (Meißner 2015). It is likely that the stimulation of the biological activity of the soil under organic and biodynamic management is due to the use of cover crop mixtures with a wide range of species, which enhances earthworm biodiversity and abundance. This effect was confirmed in different agroecosystems (Mäder et al. 2002, Blanchart et al. 2006). In contrast, Coll et al. (2011) found endogeic earthworm density and biomass to decrease under organic viticulture. Endogeic earthworms live in and feed on the soil and make horizontal burrows through the soil (Lee 1985). This result might suggest a shift in the earthworm community under organic management. The same study observed increased plant- and fungalfeeding nematode densities under organic management, as well as a decreased ratio of bacterial feeders/fungal feeders characteristic for organic farming (Coll et al. 2011).

\section{Acarian Biodiversity}

Populations of the predatory mite Typhlodromus pyri, a useful creature in vineyards for spider mite control (Duso 1989), have been shown to decrease under organic management because of the higher frequency of S sprays compared to conventional viticulture (Linder et al. 2006, Fleury and Fleury 2016). A study done in Australia, however, found abundance of predatory mites to be higher compared to conventionally managed blocks (Wheeler 2006). This could be due to a lower spraying frequency in Australia's drier conditions, or to the use of insecticides in the conventional plots. A comprehensive study in different Italian winegrowing regions that focused on predatory mite populations (Phytoseiidae and Tydeidae) in untreated, organic, and conventional vineyards found biodiversity in untreated and organic vineyards to be higher compared to conventional ones (Peverieri et al. 2009). Mite populations of untreated and organic vineyards were more similar to each other than conventional ones. This finding supports the hypothesis that arthropod biodiversity is increased under organic farming. Some predatory mite species were exclusively recorded in untreated and organic vineyards (Kampimodromus aberrans and T. pyri).

\section{Biodiversity of Insects and Spiders in the Vineyard}

Species richness of butterflies was enhanced under organic viticulture in northern Spain (Puig-Montserrat et al. 2017). The same authors investigated moth community composition in organic and conventional vineyards, but results were less significant. Conventional vineyard management is characterized by the use of wide-spectrum insecticides. Their use might affect the lepidopteran community and might therefore account for the loss of butterfly species richness under conventional viticulture. Larvae of moths are also susceptible to wide-spectrum insecticides. It remains unclear why the moth population was less affected in the latter study (Puig-Montserrat et al. 2017). Organic viticulture did not promote diversity or abundance of grasshoppers in a Swiss study (Bruggisser et al. 2010). Grasshopper diversity was even lower under organic compared to 
conventional viticulture. Grasshopper diversity was in contrast enhanced by mulching compared to mowing, which induces a lower disturbance level. The authors concluded that the background disturbance level under organic viticulture in this case was too low to be beneficial for biodiversity of grasshoppers (Bruggisser et al. 2010).

Brittain et al. (2010) investigated whether isolated organic farms provided benefits for insect pollinators and pollination services in an intensively farmed landscape in northeast Italy. According to Brittain et al. (2010), organic and conventional vineyards did not differ in their floral resources or proportion of surrounding uncultivated land. Pollinator abundance, species richness, visitation rates of pollinators, and pollination of experimental potted plants were not affected by the management system. Vegetation control within rows did not differ between the two farming systems in this study and was done by mowing. Taking into account these two characteristics of the study, it is not surprising that no differences in pollinator population or pollination services were found.

When biodiversity of arthropods was compared for organic, biodynamic, and integrated viticulture in a field trial in Germany, the organic and the biodynamic treatment showed higher numbers of arthropods in the canopy and in the green cover, as well as an increased biodiversity of arthropods (Meißner 2015). Fleury and Fleury (2016) monitored ladybird populations in organically and conventionally managed vineyards in Switzerland and observed a higher abundance, but a lower biodiversity of ladybirds under organic management. Abundance of detritivores and Collembola was assessed in two Australian studies and shown to be higher under both organic and biodynamic management (Wheeler 2006, Collins et al. 2015b) than under conventional management.

Organic viticulture increased arthropod predator biodiversity and abundance in a study conducted in northwest Italy (Caprio et al. 2015). Different species responded differently to the different farming systems. Some carabids and spiders preferred organic, and some others preferred conventional vineyards. Preference patterns of spiders in general were shown not only to be driven by the farming system itself, but also by habitat features, such as grass cover, and small-scale landscape structures, such as bushes, trees, and small forest patches. Overall biodiversity and abundance of spiders such as arthropod predators were higher in organic vineyards and even in forest patches adjacent to organic vineyards, which were typically located below the sampled vineyards. Therefore, a leaching effect of chemicals and fertilizers could explain the enhanced biodiversity in organically managed sites, since no synthetic insecticides are allowed in organic viticulture (Caprio et al. 2015).

Another study on spider community composition under organic and conventional viticulture in northwest Italy confirmed the diversity of spider species to be higher in certified organic vineyards. The level of dominance of spider species was lower for certified organic than in conventional vineyards. A low level of dominance is one important parameter for indicating biodiversity, together with high species richness and high species abundance (Isaia et al. 2006).
Landscape heterogeneity seems to be important to maintain high diversification of spider hunting strategies, which may improve natural pest control (Isaia et al. 2006, Caprio et al. 2015). In the Swiss study assessing biodiversity of plants, grasshoppers, and spiders, no difference in spider abundance or diversity was detected between organic and conventional vineyards (Bruggisser et al. 2010). As shown previously, landscape features play a major role in determining diversity of spiders (Isaia et al. 2006, Caprio et al. 2015). In the case of Ligerz in northern Switzerland (Bruggisser et al. 2010), the diversity of landscape patterns and the proximity of a nature conservation area might modify the benefits of organic viticulture assessed in other studies (Brittain et al. 2010, Nascimbene et al. 2012).

\section{Biodiversity of Birds in the Vineyard}

Birds showed no significant response to treatments comparing organic and conventional vineyards in northern Spain (Puig-Montserrat et al. 2017), nor in northeast Italy (Assandri et al. 2016). Maintaining patches of residual habitats in the vineyard and enhancing landscape heterogeneity are two key factors to increase biodiversity of avian communities in vineyards in an intensively used agricultural landscape (Assandri et al. 2016). Mobile taxa such as birds may be less influenced by the management system of one specific vineyard (Puig-Montserrat et al. 2017). Nonetheless, Caprio and Rolando (2017) detected positive effects on the feeding ecology of great tits (Parus major) under organic viticulture in northwestern Italy. Landscape variables did not differ between organic and conventional vineyards. Differences in the number of nestlings fed per visit, and the weight of the nestlings, suggest that organic vineyards offer more feeding resources. The diet of nestlings was unaffected by the management system (Caprio and Rolando 2017).

\section{Conclusions about Management Effects on Biodiversity}

Pest management strategies, application of herbicides, the diversity of cover crops, and the use of compost seem to mainly influence biodiversity in the biosphere of vineyards. Plant species richness seemed to be higher under organic management, mostly due to the absence of herbicide application. Results were dependent on the landscape context, which might modify the beneficial effects of organic viticulture on biodiversity. Results concerning the earthworm population in different trials indicate an increase in abundance under organic and biodynamic viticulture, as well as a community shift. Cover crop mixtures rich in species used in organic and biodynamic, in contrast to conventional, viticulture could be responsible for the described phenomena. Results concerning predatory mite populations in vineyards are mixed and might be very dependent on the frequency of S sprays under organic viticulture. A comprehensive study from Italy (Peverieri et al. 2009) showed untreated and organic plots to have a higher biodiversity of predatory mites compared to the conventional treatment. Results concerning the biodiversity of different insect species are mixed. In general, abundance and diversity 
of insects under organic viticulture either increased or did not differ from conventional viticulture. Results seemed to be highly dependent on the implementation of cover cropping in the organic treatment and on the landscape context. If investigated organic and conventional treatments did not differ in their flowering resources, it was unlikely that differences in insect biodiversity occurred. Some studies showed that fungicide and herbicide application in conventional viticulture had negative effects on insect biodiversity or abundance. Several studies showed the influence of landscape-induced background biodiversity in the region on biodiversity levels within the different management systems in vineyards. In intensively farmed and homogeneous landscapes, the enhanced biodiversity under organic viticulture was more evident, meaning that the landscape context might modify the beneficial effects of organic viticulture on biodiversity. The effect of the farming system seems to be more pronounced on less mobile taxa (Puig-Montserrat et al. 2017). Birds, for example, were little influenced by the management system.

The intermediate disturbance hypothesis (Grime 1973, Horn 1975, Connell 1978, Bruggisser et al. 2010) that predicted a loss of biodiversity in organically grown perennial crops due to the lower background disturbance level of organic farming must be rejected. Biodiversity in most trophic levels was enhanced under organic viticulture. Seventeen out of 24 studies showed a clear increase in biodiversity under organic viticulture. The impact of a decrease in disturbance does not only depend on the general level of disturbance, but also on the taxon investigated and the type of disturbance measured. The diversity maxima of different taxa may not be at the same position along the disturbance gradient. This is why the impact of a certain disturbance level on one taxon cannot necessarily be used to predict the impact on other taxa. Therefore, the intermediate disturbance hypothesis is only applicable for one single taxon, but not for a whole community of interacting taxa (Bruggisser et al. 2010). Organism-, site-, and crop-specific management strategies to enhance biodiversity in perennial crops should be developed. The conservation of specific taxa or organisms within an agricultural system is of high importance, because a general decrease in biodiversity within an agricultural system may lead to functional shifts when sets of species are replaced by others with different traits due to anthropogenic disturbance (Bruggisser et al. 2010).

\section{Management Effects on Vine Growth}

A reduction in vigor, expressed as pruning weight, shoot length, canopy density, or leaf area index (LAI) of organically managed vineyards compared to conventional management was observed for several white varieties such as Riesling, Kerner, and Müller-Thurgau (Hofmann 1991, Corvers 1994, Kauer 1994, Döring et al. 2015, Meißner 2015), and for the red varieties Grignolino and Cabernet Sauvignon (Malusà et al. 2004, Collins et al. 2015b, Pike 2015) (Table 2). However, LAI did not differ among treatments, according to Corvers (1994) (Riesling and Kerner). When pruning weight of organic and conventional management was compared by meta-regression analysis, taking into consideration all available data sets of scientific trials, organic and biodynamic treatments showed $21 \%$ less growth as pruning weight compared to conventional treatments (Figure 1).

Pruning weight of organic and biodynamic treatments differed from conventional/integrated treatments in the respective field trials. The environmental factors had a significant influence on the pruning weight, but no interactions between treatment and environment were observed, meaning that organic and biodynamic treatments always showed lower pruning weights regardless of the location of the trial (Supplemental Table 2). All the studies included showed an average reduction in pruning weight under organic management (Supplemental Figure 1).

The relative vegetative growth expressed as pruning weight under organic, in comparison to conventional, viticulture ranged between $57.1 \%$ and $104 \%$. No clear relationship between the level of conventional pruning weights and relative organic pruning weights could be observed, taking into account the data of field experiments available (Figure 2).

Chlorophyll content and macronutrient supply in leaves at veraison did not show differences among treatments (Linder et al. 2006, Döring et al. 2015, Meißner 2015). Danner (1985) reported a reduction of the nutrient supply for organic production in a field trial comparing organic, biodynamic, and conventional viticulture from 1979 to 1983 in Mailberg, Austria (Grüner Veltliner). N content in leaves was lower under organic and biodynamic management (Danner 1985, Malusà et al. 2004). Döring et al. (2015) showed N content in leaves at veraison under organic and biodynamic management to be higher in comparison to integrated management. At the same time, mineralized $\mathrm{N}$ content in the soil of the respective

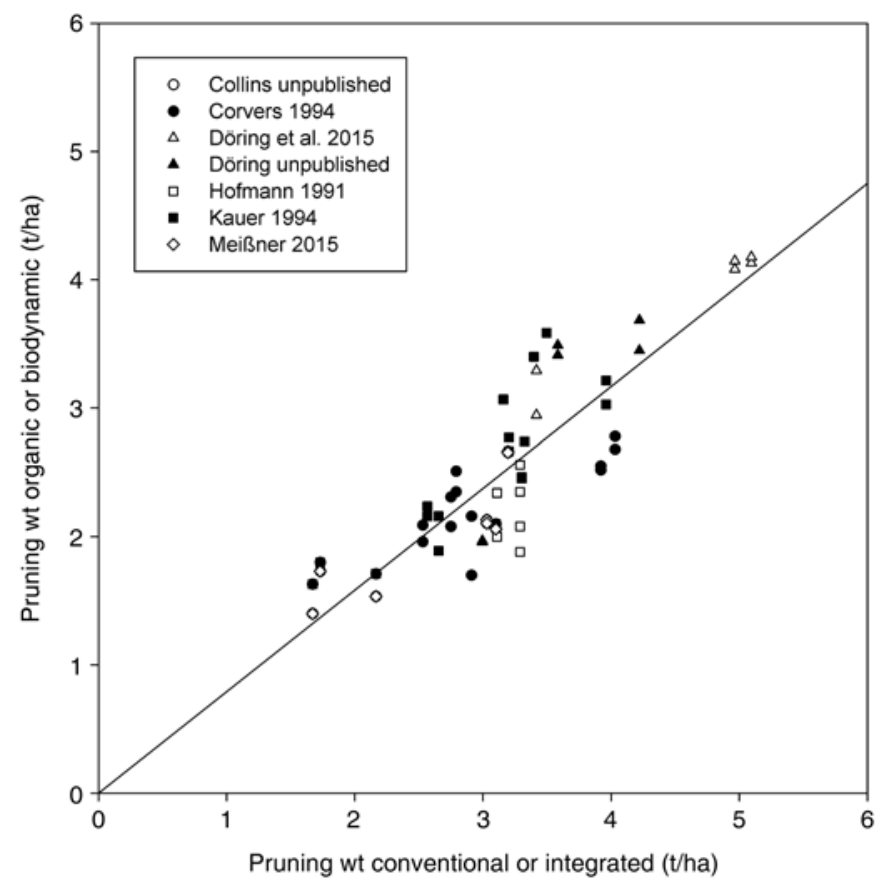

Figure 1 Growth expressed as pruning weight of conventional or integrated vineyards versus organic or biodynamic vineyards $(y=0.7921 x$; $\left.\mathrm{R}^{2}=0.74 ; \mathrm{n}=56\right)$. 
treatments was higher, as mentioned above. In the same trial, chlorophyll content was shown to decrease at veraison under organic and biodynamic management (Döring et al. 2015, Meißner 2015). Magnesium (Mg) and P content in leaves decreased under organic and biodynamic production systems compared to conventional systems in Germany and Australia (Collins et al. 2015b, Döring et al. 2015) (Table 2).

Macronutrient supply and content in leaves seems to be highly influenced by the management within organic, biodynamic, or conventional treatments. It was shown that it is possible to ensure $\mathrm{N}$ and macronutrient supply without the use of synthetic $\mathrm{N}$ fertilizers (Wheeler 2006, Probst et al. 2008, Coll et al. 2011, Collins et al. 2015b, Döring et al. 2015, Meißner 2015), although N content in the soil and in the leaves is highly dependent on fertilization strategy and water availability. It is notable that $\mathrm{P}$ content in the Australian and the German long-term field trial was lower under biodynamic management, and in Australia, also under organic management. This could be due to the lower water availability in the respective systems measured as soil moisture (Collins et al. 2015 b) or predawn water potential $\left(\Psi_{\mathrm{pd}}\right)$ (Döring et al. 2015). $\mathrm{Mg}$ content in leaves or petioles was also shown to be lower under organic and biodynamic management in both trials and might account for the decrease in chlorophyll content at veraison monitored in the organic and the biodynamic plots in the long-term trial in Germany.

Physiological performance was reported to decrease under organic and biodynamic management (Döring et al. 2015). In case of the biodynamic production system, $\Psi_{\mathrm{pd}}$ also decreased in comparison to the conventional production system in Germany, whereas no differences in stem water potential among systems could be detected close to harvest in Australia (Döring et al. 2015) (Collins and Döring, unpublished) (Table 2).

Growth and vigor expressed as pruning weight, shoot length, canopy density, or LAI decreased under organic and

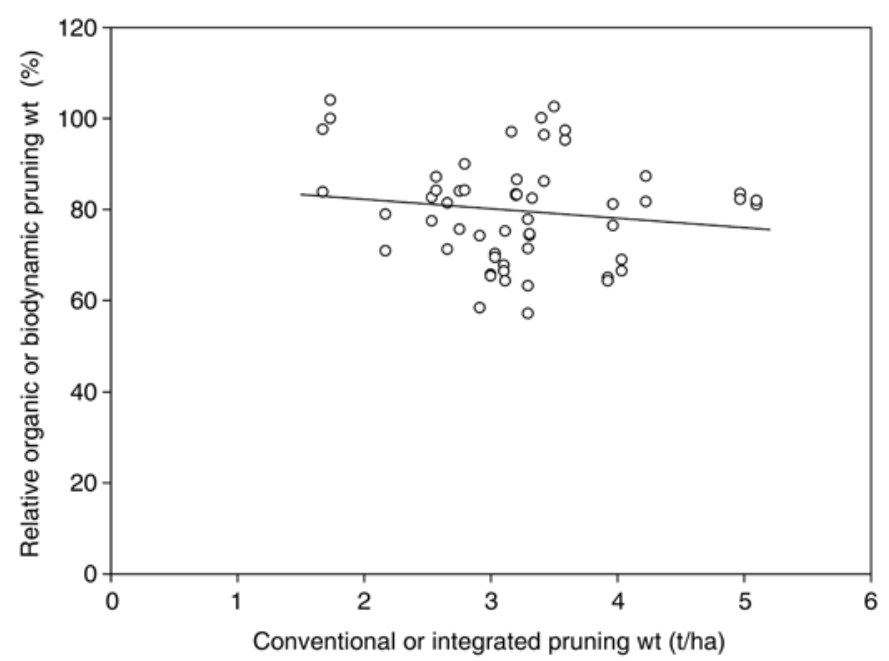

Figure 2 The relative growth expressed as pruning weight of organic or biodynamic viticulture as a function of the absolute conventional or integrated growth expressed as pruning weight from field experiments $\left(y=-2.0791 x+86.389 ; R^{2}=0.0201 ; n=56\right)$. biodynamic, in comparison to conventional, viticulture. Since in organic plots, microbial soil activity and soil organic carbon were generally higher and no consistent difference in soil N, P, or S could be observed in several field trials, these parameters cannot account for the observed differences in growth. The only study that reports a reduction in nutrient supply under organic production was performed in Austria at the beginning of the 1980 s. It seems more likely that the observed reduction in physiological performance in organic plots reported by Döring et al. (2015) might account for the growth differences between conventional and organic management. The authors observed changes in physiological performance under organic and biodynamic management after full bloom, especially under dry conditions in Germany. At the same time, $\Psi_{\mathrm{pd}}$ decreased under organic and biodynamic management. It could be hypothesized that the cover crop mixture rich in legumes used in organic and biodynamic viticulture to enhance biodiversity and to ensure $\mathrm{N}$ supply has an impact on water availability in the soil, and thus competes with the root system of the vines. Under dry conditions with irrigation in Australia, no differences in stem water potential among treatments could be observed before harvest (Collins and Döring, unpublished), although growth and canopy density in the organic and biodynamic plots decreased in the trial. This could be due to the fact that natural vegetation between rows occurs in the organic and the biodynamic system in spring when soil water availability is higher. During the dry growing season, the natural vegetation senesces, but it could still influence root growth in the respective management systems. When soil moisture was assessed in the longterm field trial in Australia during the growing season 2010 to 2011, a significant decrease of soil moisture content under organic management at $20 \mathrm{~cm}$ up to $1 \mathrm{~m}$ depth was observed compared to the high input conventional system (Collins et al. 2015b). It is likely that differences in the root system of the vines or the water availability in the soil due to cover cropping might account for different levels of plant growth regulators such as abscisic acid and cytokinin that strongly determine growth and vigor (Stoll et al. 2000).

When comparing yield/pruning weight ratios of organic and biodynamic viticulture, they were found to be significantly lower in biodynamic viticulture (Merlot) (Reeve et al. 2005) (Table 3). This difference was due to a slightly higher yield in the organic treatment, while pruning weights themselves did not differ between treatments. However, other studies did not assess differences in the yield/pruning weight ratios between organic and biodynamic plots (Collins et al. 2015b, Döring et al. 2015). No differences between organic and biodynamic treatments were observed concerning pruning weight, LAI, or leaf area-to-fruit weight ratio (Döring et al. 2015, Meißner 2015). The ratio of yield:pruning weight was significantly lower under biodynamic viticulture (Reeve et al. 2005), but the other studies showed ratios of pruning weight under organic and biodynamic management to be similar (Collins et al. 2015b, Döring et al. 2015, Meißner 2015).

Macronutrients and chlorophyll content in leaves did not differ between organic and biodynamic plots for Riesling 
(Döring et al. 2015, Meißner 2015) (Table 3). Since all nutrients are transported within the plant in the xylem, and xylem sap flow can be ensured only if there is enough plant-available soil water, nutrient supply and water uptake are closely related (Yang and Tyree 1992). Two recent studies on organic and biodynamic viticulture observed significantly lower $\Psi_{\mathrm{pd}}$ in the biodynamic plots, cv. Riesling in Germany (Döring et al. 2015) and cv. Sangiovese in Italy (Botelho et al. 2016). The relation of predawn or soil water potential and stomatal conductance of plants is usually plant- and environment-specific, but nonetheless very close (Tramontini et al. 2014). One of the two studies that observed differences in $\Psi_{\mathrm{pd}}$ between organic and biodynamic viticulture observed stomatal conductance of the biodynamic plots to be lower (Botelho et al. 2016), whereas in the other study, the lower water potential did not have implications on the physiological performance of the plants (Döring et al. 2015). In the Italian field trial where lower stomatal conductance under biodynamic viticulture occurred, a significant increase in leaf enzymatic activity (endochitinase, $\beta$-N-acetylhexoaminidase, chitin 1,4- $\beta$-chitobiosidase, $\beta$-1,3-glucanase) of the biodynamic plots for Sangiovese was observed (Botelho et al. 2016). The enzymatic activities that were found to increase under biodynamic management are linked to biotic and abiotic stress, and are associated with induced resistance against several fungi such as powdery mildew (Erysiphe necator), downy mildew ( $P$. viticola), and Botrytis bunch rot (Botrytis cinerea) (Giannakis et al. 1998, Reuveni et al. 2001, Magnin-Robert et al. 2007). One hypothesis is that especially the biodynamic horn silica preparation 501 (Table 1) made from quartz powder and used in very small quantities might upregulate plant defense mechanisms attributed to induced plant resistance (Botelho et al. 2016). However, the plots of the study by Botelho et al. (2016) were replicated, but not randomized. This is why the observed changes in physiological performance and enzymatic activity cannot clearly be attributed to the treatment and need to be confirmed.

\section{Management Effects on Yield}

A meta-analysis on annual and perennial crops under organic and conventional management reveals organic yields of individual crops to be on average $80 \%$ of conventional yields (De Ponti et al. 2012). This organic yield gap, however, may differ among crops and regions. It is hypothesized that the yield gap between organic and conventional production is higher than $20 \%$ at high yield levels and lower than $20 \%$ at low yield levels (De Ponti et al. 2012). It is hypothesized that the increasing yield gap with higher conventional yield levels may be due to yield losses by pests and diseases and/or lower $P$ availability under organic farming. The average relative yield for organically grown fruits was $72 \%$, including grapes, melon, apricot, black currant, cherry, peach, pear, and others (De Ponti et al. 2012). Another meta-analysis found yields of organically grown annual crops and animal products such as milk to be $91 \%$ of the conventional yields (Stanhill 1990).

A yield loss from $10 \%$ up to $30 \%$ is reported for organic viticulture, compared to conventional production for several white varieties such as Riesling, Kerner, Müller-Thurgau, Grüner Veltliner, Chardonnay, and Seyval, and for red varieties Grignolino, Cabernet Sauvignon, Merlot, Shiraz, and Concord (Danner 1985, Hofmann 1991, Corvers 1994, Kauer 1994, Pool and Robinson 1995, Malusà et al. 2004, Wheeler 2006, Collins et al. 2015a, Döring et al. 2015, Meißner 2015) (Table 2). Meta-regression analysis shows that organic and biodynamic treatments have on average $18 \%$ less yield compared to conventional treatments (Figure 3). The average yield gap observed in viticulture is similar to that in annual crops.

Yield of organic and biodynamic treatments differed from conventional/integrated treatments in the respective field trials. The environmental factors had a significant influence on the yield levels, but no interactions between treatment and environment were observed, meaning that organic and biodynamic treatments always showed significantly lower yields regardless of the location of the trial (Supplemental Table 2). All the studies included in the meta-analysis and the metaregression showed lower average yields for organic or biodynamic, compared to conventional, management (Supplemental Figure 2).

The yield gap under organic compared to conventional viticulture ranges from $44.2 \%$ to $119.4 \%$ for the data included in the meta-analysis. Looking at the relative organic yield in proportion to the yield level of the conventional or integrated counterpart, no clear relationship between conventional yield level and relative organic yield can be observed (Figure 4), meaning that organic relative yields do not automatically decrease when yield levels increase in conventional viticulture.

In the case of Chasselas in Perroy (Waadt, Switzerland) (Linder et al. 2006), Riesling in Geisenheim (Rheingau, Germany) (Döring et al. 2015, Meißner 2015), and Elvira in Geneva (New York, US) (Pool and Robinson 1995), a reduction

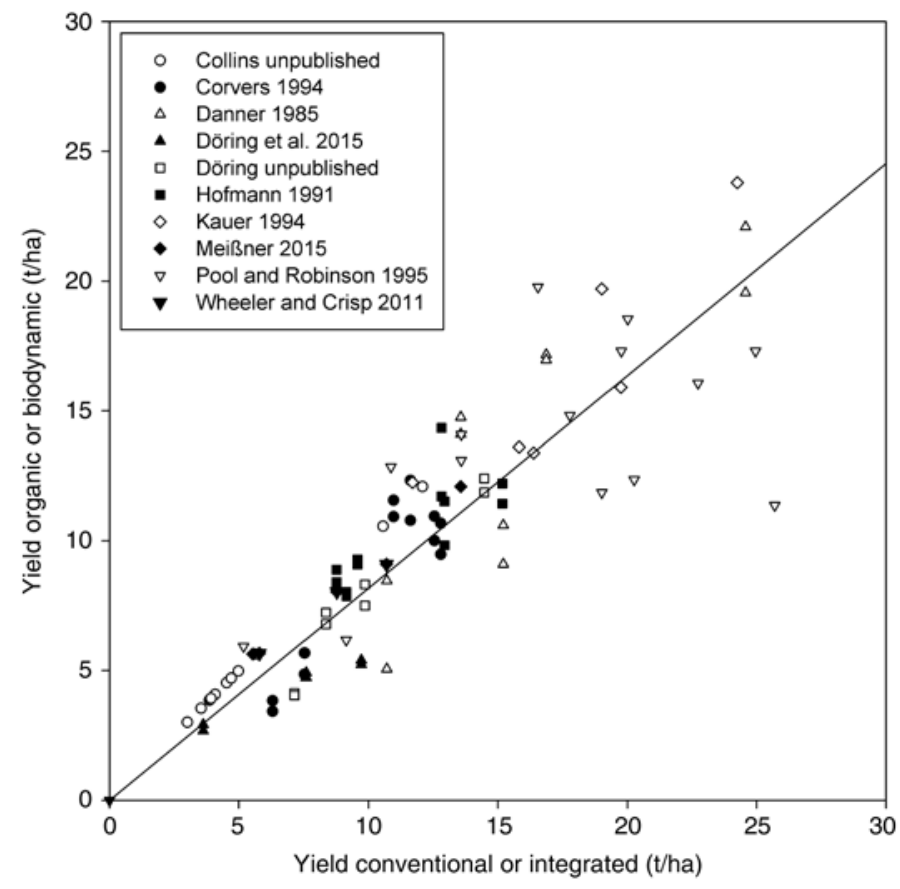

Figure 3 Yield of conventional and integrated vineyards versus organic and biodynamic managed vineyards $\left(y=0.8184 x ; R^{2}=0.80 ; n=92\right)$. 
of the berry weight under organic and biodynamic production was observed. In contrast, single berry weight did not differ among treatments from 1990 to 1992 in Erbach and Hattenheim (Rheingau, Germany) (Riesling and Kerner) (Corvers 1994), and from 1990 to 1994 in Geneva (New York, US) (Concord and Seyval) (Pool and Robinson 1995) (Table 2).

Organic and biodynamic plots showed lower compactness of bunches (Riesling) (Döring et al. 2015, Meißner 2015). The number of berries/bunch and the average bunch weight were significantly lower under organic and biodynamic management in the Corvers (1994) and Döring et al. (2015) studies, but Pool and Robinson (1995) did not report a difference in the number of berries/bunch and the average bunch weight between management systems (Table 2). The reduced berry weights, reduced bunch weights, and reduced number of berries/bunch that were observed under organic and biodynamic management in many trials could be due to different water availability in the soil (Collins et al. 2015b) and a reduced physiological performance around full bloom (Döring et al. 2015); these could be reasons for the yield decrease described above. Fruit set was not assessed in any of the trials, but fruit set is likely to differ between treatments, because the treatments were shown to differ in growth, water availability in the soil, and physiological performance at full bloom.

Döring et al. (2015) provided evidence that the vine water status, and thus the physiological performance, differ between organic or biodynamic and conventional viticulture. Since reproductive development of Vitis vinifera is highly sensitive to the water and $\mathrm{N}$ status, the lower water availability in the organic and the biodynamic management system might account for the differences in physiological performance and might cause yield differences. Lower water availability early in the season was shown to cause decreases in yield and cluster weight (Matthews and Anderson 1989). Since the period from initiation to maturation of winegrapes comprises two growing seasons, early season water deficit might have implications for cluster weight of the current year and the number

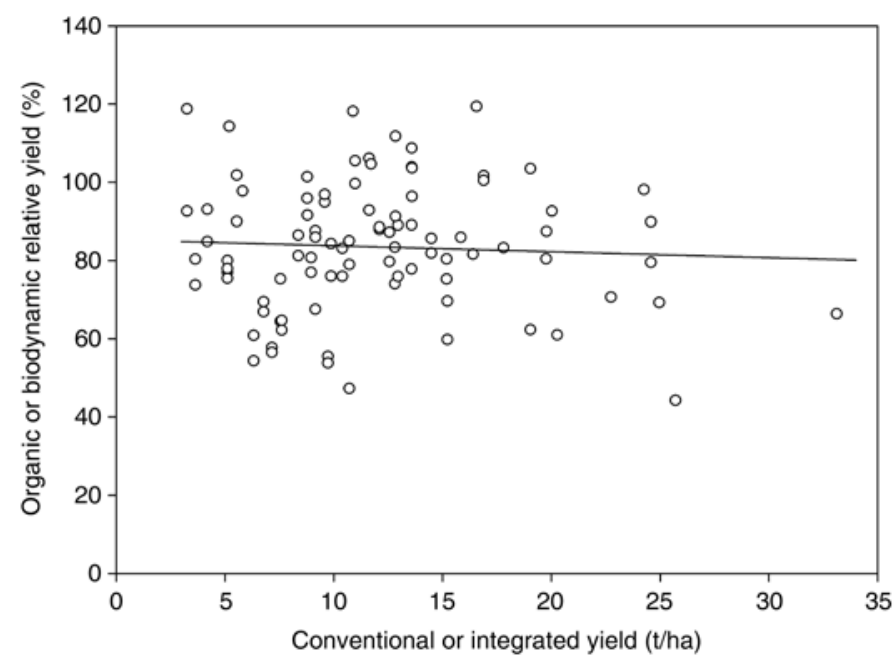

Figure 4 The relative yield of organic or biodynamic viticulture as a function of the absolute conventional or integrated yield from field experiments $\left(y=-0.1526 x+85.348 ; R^{2}=0.003 ; n=92\right)$. of clusters of the subsequent year (Matthews and Anderson 1989, Döring et al. 2015). There is evidence that water availability in hot as well as in cool climate viticulture plays a key role in determining vigor and yield under organic and biodynamic viticulture. How $\mathrm{P}$ and $\mathrm{Mg}$ availability are influenced by the different water availability in the different viticultural management systems should be a subject of further research. It is still unclear to what extent the lower P and Mg availability under organic and biodynamic viticulture determines growth and yield of the respective systems.

No yield differences were observed between organic and biodynamic treatments for Merlot, Sangiovese, Cabernet Sauvignon, and Riesling (Reeve et al. 2005, Collins et al. 2015a, Döring et al. 2015, Meißner 2015, Botelho et al. 2016) (Table 3). Danner (1985) detected lower yields for the biodynamic plots than for the organic plots in two out of five years of the study done in Austria on Grüner Veltliner. The organic and the biodynamic treatments did not differ in the number of bunches/vine, cluster weight, cluster compactness, or berry weight (Reeve et al. 2005, Döring et al. 2015, Meißner 2015).

\section{Management Effects on Disease Incidence}

Disease incidence of downy mildew ( $P$. viticola) did not show any differences comparing organic, biodynamic, and conventional production for Grüner Veltliner in Austria under higher disease pressure, and for Cabernet Sauvignon in Australia under low disease pressure (Danner 1985, Pike 2015). For Riesling under more humid climatic conditions, the incidence of downy mildew was significantly higher under organic and biodynamic production when the disease occurred (Döring et al. 2015) (Table 2). For Chasselas in Switzerland, the organic treatment showed significantly higher disease incidence of powdery mildew (E. necator) (Linder et al. 2006). Results are mixed concerning the disease incidence of Botrytis bunch rot (B. cinerea). Danner (1985) reported that the organic treatment showed a higher disease incidence of Botrytis bunch rot compared to the biodynamic and the conventional treatment in three out of five years, whereas the biodynamic treatment showed a higher disease incidence of Botrytis bunch rot in just one out of five years, compared to the conventional system. For Riesling, the organic and biodynamic plots showed lower disease incidence of Botrytis bunch rot compared to the integrated plot from 2006 to 2009 (Meißner 2015). The field trial was managed and conducted in the same way after conversion. In the following years of the same field trial from 2010 to 2012, the biodynamic treatment showed significantly higher disease incidence of Botrytis bunch rot compared to the integrated management system, whereas the organic treatment did not differ from the integrated plots (Döring et al. 2015) (Table 2). Under dry conditions in Australia, the organic and the biodynamic plots did not differ from the conventional plots with respect to disease incidence of Botrytis (Pike 2015). This might be due to the low disease pressure under Australian conditions and Cabernet Sauvignon bunch architecture preventing infections of Botrytis bunch rot (Table 2). The organic and the biodynamic system showed significantly less sour rot on bunches in the 
field trial in Geisenheim (Rheingau, Germany) (Döring et al. 2015, Meißner 2015).

The direct comparison of biodynamic versus organic viticulture revealed a higher disease incidence of Botrytis under organic management in three out of five years in the field trial in Austria (Danner 1985), but no difference was detected in the field trial in Germany (Döring et al. 2015) or in Australia (Pike 2015) (Table 3). Organic and biodynamic viticulture did not differ in the disease incidence of downy mildew (Danner 1985, Döring et al. 2015, Pike 2015).

Disease incidence seems to be highly dependent on the grapevine variety, the location and its microclimate, the vineyard management, and the environmental conditions of each year. Still, it is not surprising that disease incidence of some grapevine diseases such as powdery and downy mildew is higher under organic or biodynamic management compared to conventional viticulture, since the organic and the biodynamic systems exclusively rely on fungicides such as $\mathrm{Cu}$ and $\mathrm{S}$ and on plant resistance improvers. All these agents are strictly protectants and they do not act curatively, as some synthetic fungicides do. Besides that, no botryticides are applied in organic or biodynamic viticulture. Döring et al. (2015) quantified the potential yield loss in organic and biodynamic viticulture due to downy mildew over a three-year-period and concluded that only up to $10 \%$ of the observed yield reduction in organic and biodynamic management could be attributed to the infestation with downy mildew in the year with the most severe attack of downy mildew. This clearly underlines that other mechanisms must play a key role in causing the yield gap between organic and conventional production.

\section{Management Effects on Fruit, Juice Composition, and Wine Quality}

The impact of organic viticulture on grape quality parameters, juice, and wine quality is inconclusive (Table 2). In a number of trials, no consistent differences were observed in grape composition of several researched grape varieties (Danner 1985, Hofmann 1991, Kauer 1994, Henick-Kling 1995, Malusà et al. 2004, Linder et al. 2006, Tassoni et al. 2013, 2014, Collins et al. 2015a, 2015b, Döring et al. 2015), whereas Hofmann (1991) reported differences in winegrape quality between organic and conventional production, depending on plant protection strategy and incidence of Botrytis at harvest. Coffey (2010) detected higher levels of zinc and iron (Fe) in berries from organic management (Cabernet Sauvignon) in Australia. Corvers (1994) and Meißner (2015) observed that the integrated treatment showed significantly higher must acidity for the varieties Riesling and Kerner, in Germany, whereas in a study in Italy, organic Sangiovese wines had higher malic acid and volatile acidity (Beni and Rossi 2009). Tobolková et al. (2014) detected higher citric acid in Slovakian white wines from conventional management. No differences in juice and wine quality were observed, including acidity, macronutrients, and phenolic compounds (Danner 1985, Kauer 1994, Henick-Kling 1995, Dupin et al. 2000, Granato et al. 2015b, 2015c, 2016, Meißner 2015) (Table 2). Fritz et al. (2017) assessed juice quality in the first year of conversion according to image-forming methods (biocrystallization, capillary dynamolysis, and circular chromatography image analysis [Huber et al. 2010, Zalecka et al. 2010]), and ranked grape juices from organic and biodynamic plots better than grape juices from integrated plots due to their strength of form expression and their resistance to deterioration (Riesling). Cozzolino et al. (2009) correctly classified $85 \%$ of their samples of Australian organic and nonorganic wines according to mid-infrared spectra by discriminant partial least squares. Meta-regression analysis shows that the juice sugar concentration of organically and biodynamically managed vineyards was almost the same as that of conventionally managed vineyards (Figure 5).

TSS in juice of organic and biodynamic treatments did not differ from conventional/integrated treatments in the respective field trials. The geographic location of the trials had a significant influence on levels of TSS, but no interactions between treatment and environment were observed, meaning that organic and biodynamic treatments never differed from conventional treatments in TSS in juice regardless of the location (Supplemental Table 2). All the studies included in the meta-analysis and meta-regression showed similar amounts of TSS for organic and conventional management (Supplemental Figure 3).

It was shown that growth and yield of grapevines under organic and biodynamic management generally decrease. One very important parameter determining potential level of TSS in grape juice is the leaf area-to-fruit weight ratio (Kliewer and Dokoozlian 2005). Döring et al. (2015) measured this ratio under integrated, organic, and biodynamic management.

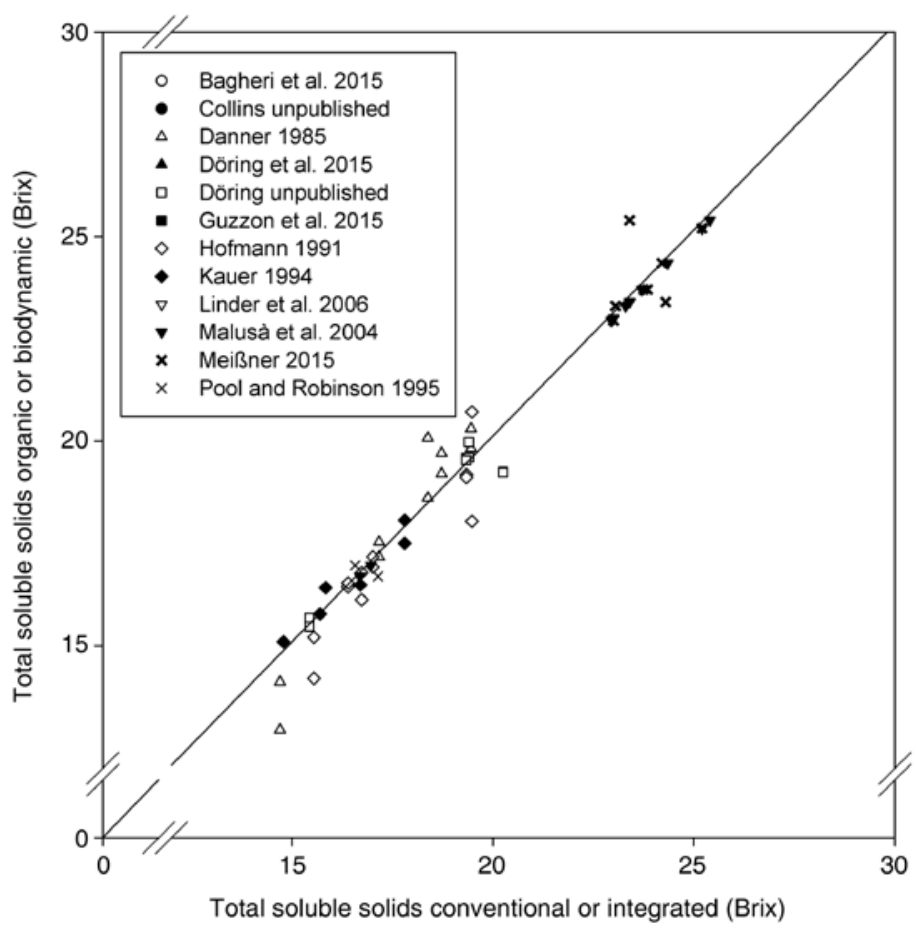

Figure 5 Juice sugar concentration of conventionally or integrated vineyards versus organically or biodynamically managed vineyards $\left(y=1.0068 x ; R^{2}=0.96 ; n=85\right)$. 
The organic and the biodynamic treatments showed slightly higher levels of leaf area-to-fruit weight ratio, but there was no difference among treatments. One reason why organically and biodynamically managed vineyards do not differ from conventional vineyards in TSS in juice could be the simultaneous decrease of growth and yield, resulting in a similar ratio of leaf area to fruit weight. Results by Collins et al. (2015b) concerning the ratio of yield-to-pruning weight support that there is no difference among the systems concerning the ratio of reproductive and vegetative growth. Another reason for the fact that systems did not differ in the amount of TSS at harvest might be that physiological performance (assimilation rate, transpiration rate, and stomatal conductance) after veraison, which highly determines final sugar content and berry quality traits, did not differ among treatments when measured in the long-term field trial in Germany (Hardie and Considine 1976, Döring et al. 2015).

Yeast-available N content (N-OPA) was shown to increase under biodynamic management after conversion (Döring et al. 2015), but N-OPA content did not differ among treatments in the first years of the same trial (Meißner 2015). The application of systemic fungicides in the integrated plot (Oliva et al. 2011) and the lower content of $\mathrm{N}$ in the soil of the integrated plots together with the high yields may have caused the decrease in N-OPA levels in berries of the integrated treatment (Döring et al. 2015).

Yildirim et al. (2007) found putrescine content to be significantly higher under organic viticulture, while Tassoni et al. (2013) did not detect differences in the content of biogenic amines in wines from different management systems.

There is evidence that anthocyanin and flavonoid content in berry skin; polyphenol content, antioxidant potential, and phenolic acid content in juice and wine; and resveratrol content and enzyme polyphenol oxidase concentration in grapes increase under organic management (Tinttunen and Lehtonen 2001, Micelli et al. 2003, Malusà et al. 2004, Yildirim et al. 2004, Núñez-Delicado et al. 2005, Otreba et al. 2006, Dani et al. 2007, Vrček et al. 2011, Rodrigues et al. 2012, Buchner et al. 2014, Granato et al. 2015a). Other studies did not observe any differences in the polyphenol or anthocyanin profiles of grapes and wines, their carotenoid and trans-resveratrol content, content of $p$-coumaric acid, or their antioxidant activity (Lante et al. 2004, Mulero et al. 2009, 2010, Bunea et al. 2012, Tassoni et al. 2013, Collins et al. 2015a, 2015b, Garaguso and Nardini 2015). Total polyphenol content and antioxidant activity in wines even decreased under organic viticulture in some other studies (Yildirim et al. 2004, Beni and Rossi 2009). Moreover, ascorbic acid equivalents, ferric-reducing power, and $\mathrm{Cu}$ and $\mathrm{Fe}$ in wines were found to be reduced in organic viticulture (Tobolková et al. 2014).

It is likely that the different treatments produced different polyphenol contents, since the synthesis of these parameters is highly linked to light interception in the canopy. Organic and biodynamic treatments showed significantly lower growth, lower canopy density, and lower secondary shoot growth. This lower vigor might induce higher levels of flavonoids and anthocyanins, and thus a higher antioxidant potential (Cortell et al. 2005). On the other hand, the organic and the biodynamic plots also had lower yields, which might result in no change in the polyphenol content. Fruit-zone leaf removal potentially has a strong effect on light interception, and thus on phenolic composition of the grapes. In the trials comparing the different management systems, fruit-zone leaf removal was not implemented so as not to interfere too much with the systems' performance.

Several studies focused on grape composition under organic and biodynamic viticulture, including TSS, acidity, macronutrients, and phenolic compounds. Most of the studies revealed that there was no difference for varieties such as Grüner Veltliner, Merlot, Pignoletto, Sangiovese, Cabernet Sauvignon, Albana, Lambrusco, and Riesling (Danner 1985, Reeve et al. 2005, Tassoni et al. 2013, 2014, Laghi et al. 2014, Collins et al. 2015b, Döring et al. 2015, Granato et al. 2015a, 2015c, Meißner 2015, Parpinello et al. 2015, Picone et al. 2016, Patrignani et al. 2017) (Table 3). Almost all the studies included in the meta-analysis and meta-regression showed similar levels of TSS for organic and biodynamic viticulture.

Nonetheless, some authors assessed differences in the chemical composition of berries, juices, or wines grown organically and biodynamically (Table 3). Meißner (2015) detected a lower juice acidity in fruit managed biodynamically (Riesling). Fritz et al. (2017) assessed juice quality in the first year of conversion according to image-forming methods (biocrystallization, capillary dynamolysis, and circular chromatography image analysis [Huber et al. 2010, Zalecka et al. 2010]), and ranked grape juices from biodynamic plots better than grape juices from organic plots (Riesling). Some studies revealed that there was an increase in total phenols, total anthocyanins, and $\gamma$-aminobutyric acid, as well as amino acids and organic acids under biodynamic viticulture for Sangiovese and Merlot (Reeve et al. 2005, Laghi et al. 2014, Picone et al. 2016). Laghi et al. (2014), Parpinello et al. (2015), and Picone et al. (2016) detected a decrease in sugars, alcohol content, phenolic compounds, wine color, total polymeric pigments, and tannins, as well as coumaric and trans-caffeic acid (cv. Sangiovese). One hypothesis could be that the lower stomatal conductance, as observed in biodynamically managed plants, led to a higher concentration of internal $\mathrm{CO}_{2}$ (Botelho et al. 2016, Picone et al. 2016). A higher internal $\mathrm{CO}_{2}$ concentration could then lead to a predominance of the anaerobic metabolism in biodynamically grown berries compared to organically grown berries (Picone et al. 2016). It is thought that in berries of biodynamic management, the fermentative pathway is activated (Picone et al. 2016). Lower sugar concentration and an increased concentration of organic acids such as lactate and malate in biodynamically grown berries might be signs of the activation of the anaerobic metabolism (Picone et al. 2016), although further research is needed to confirm this hypothesis. Moreover, the field trial on Sangiovese had no randomized field replicates (Laghi et al. 2014, Parpinello et al. 2015, Botelho et al. 2016, Picone et al. 2016). This is why it is not clear whether the observed phenomena are an effect of the plot or of the treatment. 
Results by Meißner (2015) suggested a lower juice acidity in biodynamically grown grapes, which is contrary to a higher concentration of organic acids, as found by Picone et al. (2016). The increase of phenolic compounds under biodynamic management, as described by Reeve et al. (2005), could confirm the hypothesis of an upregulation of substances attributed to induced resistance in biodynamically grown plants, as expressed by Botelho et al. (2016). Still, Parpinello et al. (2015) found that total polymeric pigments, tannin concentration, and total color under biodynamic management decreased in the first two years after conversion, but again this field trial did not have randomized replicates.

\section{Management Effects on Fruit and Wine Sensory Characteristics}

Berries derived from the long-term trial in Australia on Cabernet Sauvignon were submitted to berry sensory analysis in order to assess grape sensory pulp properties. Berries from organic management resulted in having a significantly higher pulp juiciness compared to berries from the conventional treatment in the third year of conversion (Coffey 2010).

Results concerning the sensory characteristics of wines derived from organic and conventional management are heterogenic. Wines derived from several field trials revealed no influence of management on wine sensory characteristics when rank sum tests were applied (Danner 1985, Kauer 1994, Meißner 2015). Martin and Rasmussen (2011) compared pairs of organically and conventionally grown wines that differed in their total polyphenol concentration, but found no difference in the sensory characteristics. Dupin et al. (2000) compared commercially available wines of organic and conventional production and did not observe differences in the wine sensory attributes. However, in two of these studies, the wines from conventional management were perceived as more floral, fruity, vegetal, and complex (Dupin et al. 2000, Meißner 2015), whereas the wines from biodynamic management tended to be more balanced and full-bodied, with a stronger minerality and more length (Meißner 2015). In this study, wines from biodynamic management were preferred by the tasting panels in rank sum tests (Meißner 2015). Wines from the Australian long-term-trial on Cabernet Sauvignon were characterized by quantitative descriptive analysis, and wines from organic and biodynamic plots were assessed as more rich, textural, complex, and vibrant in comparison to wines from conventionally managed plots (Collins et al. 2015a). Henick-Kling (1995) found wines from organic management (Seyval) to be significantly more spicy and less skunky compared to conventional wines, and panelists preferred the wine from organic plots. Organically grown Sangiovese wines from an Italian field trial were described as less astringent with a higher overall acceptance by the sensory panel (Beni and Rossi 2009). Trebbiano wines from the same trial were described as unbalanced and acidic with respect to the organic product (Beni and Rossi 2009).

No differences could be detected in sensory characteristics of the wines between organic and biodynamic management for Grüner Veltliner and Sangiovese (Danner 1985, Collins et al. 2015a, Parpinello et al. 2015, Patrignani et al. 2017). By contrast, Meißner (2015) reported a sensorial preference of Riesling wines from biodynamic management in comparison to the ones from the organic plots. Ross et al. (2009) detected differences between Merlot wines from organic and biodynamic plots of a field trial in two out of four years, but sensory characteristics attributed to the different wines were not consistent over the years.

\section{Management Effects on Production Costs and Efficiency}

The increase in production costs for organic and biodynamic viticulture assessed in Europe, the US, and Australia ranged between 7 and $90 \%$ compared to conventional production, although the increase in costs was highly dependent on the size of the winery and the timespan since conversion (Danner 1985, White 1995, Linder et al. 2006, Delmas et al. 2008, Santiago 2010, Santiago and Johnston 2011, Collins et al. 2015b). The increase in production costs was mainly due to yield reduction and higher costs for under-vine weed control and compost management, whereas costs for irrigation and canopy management decreased (Santiago 2010, Santiago and Johnston 2011). Wheeler (2006) found input costs as well as labor input costs of organic viticulture to be higher compared to conventional viticulture. In the long-term field trial in Australia, organic and biodynamic viticulture produced $74 \%$ and $65 \%$, respectively, of the gross margins compared to high-input conventional viticulture (Collins et al. 2015b). Guesmi et al. (2012) investigated the productive efficiency of organic and conventional wineries in Catalonia and found organic farms to have higher efficiency ratings than conventional farms in the area, mostly due to improved agricultural performance, better management of their inputs, and organic price premiums. Biodynamic viticulture in a Spanish study showed substantially lower environmental burdens compared to conventional viticulture determined by life cycle assessment (Villanueva-Rey et al. 2014).

The life cycle assessment in this case compares all inputs and outputs (trellises, fertilizers, pesticides, energy, water, field operations, and emissions) for a production system, e.g., for producing a certain amount of grapes. It evaluates their environmental impact for different forms of viticulture (Villanueva-Rey et al. 2014). Kavargiris et al. (2009) found total energy inputs, fertilizer and plant protection products application, fuel inputs, and greenhouse gas emissions to be higher in conventional compared to organic wineries of the same size in Greece. On the other hand, grape yield, pomace, and ethanol from pomace were also higher in conventional wineries (Kavargiris et al. 2009). According to Delmas et al. (2008), costs for biodynamic grapegrowing are between 10 and $15 \%$ higher than for organic grapegrowing. Santiago (2010) found biodynamic wineries in Australia to have only $7 \%$ higher operational costs, including canopy and under-vine management costs, than organic wineries. The same study highlighted that large biodynamic wineries had lower operational costs/ha compared to organic wineries, in some cases, even lower operational costs/ha compared to conventional 
wineries (Santiago 2010). Overall costs for winemaking are similar for conventional, organic, and biodynamic wine (Delmas et al. 2008).

\section{Conclusions}

Stimulation of soil nutrient cycling by compost application, the implementation of cover crop mixtures with a wide range of species, and denial of mineral fertilizers and herbicides, as practiced in organic and biodynamic viticulture, take some years to make an impact on $\mathrm{N}$ levels and on microbial activity in the soil. This is why long-term field trials seem to be crucial for a better understanding of the management systems. The contribution of soil microbial communities to soil fertility and the consequences on plant growth, especially in comparison to mineral fertilization, are little understood and need more scientific attention to characterize the underlying phenomena.

Biodiversity at different trophic levels was enhanced under organic and biodynamic viticulture compared to conventional management. Seventeen out of 24 studies showed a clear increase in biodiversity under organic and biodynamic viticulture. Pest management strategies, herbicide application, addition of compost, and diversity of cover crops seem to mainly influence biodiversity in the biosphere of vineyards. The contribution of an enhanced biodiversity to abundance and biodiversity of antagonistic insects in the vineyard should be further investigated and quantified.

Growth of vines expressed as pruning weight under organic and biodynamic viticulture decreased by $21 \%$, although single study outcomes were heterogenic. This might be due to different soil water availability in organic viticulture, which might result in a lower physiological performance, especially after full bloom. It is likely that differences in the root systems of the vines or the water availability in the soil due to cover cropping might account for different levels of plant growth regulators, such as gibberellic acid, cytokinin, and auxin, which strongly determine growth and vigor. The mechanisms that influence growth in organic and biodynamic viticulture should be further investigated by assessing hydraulic conductivity, stomatal conductance, and phytohormone contents at the same time.

A yield decrease of $18 \%$ in organic and biodynamic viticulture compared to conventional viticulture was observed when all available data from scientific field trials were assessed. Since reproductive development of $V$. vinifera is highly sensitive to water status, the lower water availability and the lower physiological performance after full bloom in the organic and the biodynamic management systems might cause yield differences. Since the period from initiation to maturation of winegrapes comprises two growing seasons, early season water deficit might have implications for cluster weight of the current year and the number of clusters of the subsequent year. More information about the influence of differing soil moisture content and physiological performance of the management systems on fruit set should be gained in the future.

Treatments did not differ in TSS in juice. It was shown that growth and yield of grapevines under organic and biodynamic management generally decrease. One very important parameter determining potential levels of TSS in grape juice is the leaf area-to-fruit weight ratio. One reason why organically and biodynamically managed vineyards do not differ from conventional vineyards in TSS in juice could be the simultaneous decrease of growth and yield that results in a similar ratio of leaf area to fruit weight.

Organic and biodynamic treatments showed significantly lower growth, lower canopy density, and lower secondary shoot growth. This lower vigor might induce higher levels of flavonoids and anthocyanins, and thus a higher antioxidant potential due to greater light exposure. However, just two out of four studies found anthocyanin and flavonoid content in berry skin and polyphenol contents in wine to differ between organic and conventional management. Further investigations are necessary to understand possible interactions among management systems, trellis systems, and varieties.

Many studies that assessed wine quality and wine sensory characteristics among conventional, organic, and biodynamic viticulture are inconsistent in their findings. More research is needed on grape, juice, and wine compositional analysis to better understand how differences of sensory characteristics perceived by several panels in quantitative descriptive analyses can be supported with reasoning. Grapes, juices, and wines from replicated field trials with representative distribution of plots should be used for this to clearly relate the outcome to the different management practices.

Studies included in the meta-analysis were partially heterogenic and limited in number. Moreover, some locations, such as Europe, were overrepresented in the meta-analysis due to data availability and frequency of trials in this area comparing conventional and organic viticultural production. This study nonetheless did not assess any interactions between location of the trials and treatments, but locations differed in their growth level, yield level, and level of TSS in juice. This is why when calculating the ratio of organic to conventional growth rate, yield, and TSS, European results were overestimated.

Future research should concentrate on the optimization of organic and biodynamic viticultural practices in the different environments concerning macronutrient supply, disease incidence, yields, and cost structure. One focus of future research should be how to increase biodiversity in perennial cropping systems in comparison to habitats that are not used agriculturally. The impact of an increase in biodiversity on vine pests and diseases to determine the benefits of these ecosystem services is one other major issue for future research. On the other hand, possible interactions of the management systems with different varieties, trellis systems, soil types, rootstocks, and irrigation regimes should be detected to determine more effective viticultural management systems.

The comparison of biodynamic and organic viticulture showed similar characteristics. Two recent studies on organic and biodynamic viticulture observed significantly lower $\Psi_{\mathrm{pd}}$ in the biodynamic plots. One of the two studies observed lower stomatal conductance of the biodynamic plots. At the same time, a significant increase in leaf enzymatic activity of the biodynamic plots for Sangiovese was observed. One 
hypothesis is that especially the horn silica preparation 501 made from quartz powder might upregulate plant defense mechanisms attributed to induced plant resistance. This again might have implications for berry composition under biodynamic management. These hypotheses need confirmation, especially because the only study that has assessed these phenomena did not have randomized field replicates. This is why these observations cannot be clearly attributed to the biodynamic treatment.

In the viticultural trials included in this study, the application of the biodynamic preparations was one characteristic of the biodynamic plots, but livestock, which is one essential component of a biodynamic farm, was not included. It is very difficult to include this in randomized scientific field trials. On-farm experiments with a scientific setup might be more suitable in order to depict biodynamic farming and to draw conclusions on this specific management system.

\section{Literature Cited}

Altieri MA. 1999. The ecological role of biodiversity in agroecosystems. Agr Ecosyst Environ 74:19-31.

Assandri G, Bogliani G, Pedrini P and Brambilla M. 2016. Diversity in the monotony? Habitat traits and management practices shape avian communities in intensive vineyards. Agr Ecosyst Environ 223:250-260.

Bagheri B, Bauer FF and Setati ME. 2015. The diversity and dynamics of indigenous yeast communities in grape must from vineyards employing different agronomic practices and their influence on wine fermentation. S Afr J Enol Vitic 36:243-251.

Bengtsson J, Ahnström J and Weibull AC. 2005. The effects of organic agriculture on biodiversity and abundance: A meta-analysis. J Appl Ecol 42:261-269.

Beni C and Rossi G. 2009. Conventional and organic farming: Estimation of some effects on soil, copper accumulation and wine in a Central Italy vineyard. Agrochimica 53:145-159.

Blanchart E, Villenave C, Viallatoux A, Barthès B, Girardin C, Azontonde A and Feller C. 2006. Long-term effect of a legume cover crop (Mucuna pruriens var. utilis) on the communities of soil macrofauna and nematofauna, under maize cultivation, in southern Benin. Eur J Soil Biol 42:S136-S144.

Botelho RV, Roberti R, Tessarin P, Garcia-Mina JM and Rombolà AD. 2016. Physiological responses of grapevines to biodynamic management. Renew Agr Food Syst 31:402-413.

Brittain C, Bommarco R, Vighi M, Settele J and Potts SG. 2010. Organic farming in isolated landscapes does not benefit flower-visiting insects and pollination. Biol Conserv 143:1860-1867.

Bruggisser OT, Schmidt-Entling MH and Bacher S. 2010. Effects of vineyard management on biodiversity at three trophic levels. Biol Conserv 143:1521-1528.

Buchner I et al. 2014. Hepatoprotective and antioxidant potential of organic and conventional grape juices in rats fed a high-fat diet. Antioxidants 3:323-328.

Bunea CI, Pop N, Babes AC, Matea C, Dulf FV and Bunea A. 2012. Carotenoids, total polyphenols and antioxidant activity of grapes (Vitis vinifera) cultivated in organic and conventional systems. Chem Cent J 6:66.

Caprio E and Rolando A. 2017. Management systems may affect the feeding ecology of great tits Parus major nesting in vineyards. Agr Ecosyst Environ 243:67-73.

Caprio E, Nervo B, Isaia M, Allegro G and Rolando A. 2015. Organic versus conventional systems in viticulture: Comparative effects on spiders and carabids in vineyards and adjacent forests. Agr Syst 136:61-69.

Castellini A, Mauracher C and Troiano S. 2017. An overview of the biodynamic wine sector. Int J Wine Res 9:1-11.

Coffey C. 2010. Quantitative analysis of grape berries from vines managed using organic, biodynamic and conventional viticulture. School of Agriculture, Food and Wine. The University of Adelaide, Adelaide, p. 60.

Coll P, Le Cadre E, Blanchart E, Hinsinger P and Villenave C. 2011. Organic viticulture and soil quality: A long-term study in Southern France. Appl Soil Ecol 50:37-44.

Collins C, Penfold CM, Johnson LF, Bastian S and Marschner P. 2015a. The relative sustainability of organic, biodynamic and conventional viticulture. GiESCO, Peche Rouge, pp. 53-55.

Collins C, Penfold CM, Johnson LF, Marschner P and Bastian S. 2015b. The relative sustainability of organic, biodynamic and conventional viticulture. Final Report to Australian Grape and Wine Authority. The University of Adelaide, Australia.

Connell JH. 1978. Diversity in tropical rain forests and coral reefs. Science 199:1302-1310.

Cortell JM, Halbleib M, Gallagher AV, Righetti TL and Kennedy JA. 2005. Influence of vine vigor on grape (Vitis vinifera L. cv. Pinot noir) and wine proanthocyanidins. J Agric Food Chem 53:5798-5808.

Corvers M. 1994. Auswirkungen von verschiedenen systemen der bewirtschaftung auf die rebe und den wein in versuchen auf dem standort mariannenaue. Justus-Liebig-Universität Gießen.

Cozzolino D, Holdstock M, Dambergs RG, Cynkar WU and Smith PA. 2009. Mid infrared spectroscopy and multivariate analysis: A tool to discriminate between organic and non-organic wines grown in Australia. Food Chem 116:761-765.

Dani C, Oliboni LS, Vanderlinde R, Bonatto D, Salvador M and Henriques JA. 2007. Phenolic content and antioxidant activities of white and purple juices manufactured with organically- or conventionallyproduced grapes. Food Chem Toxicol 45:2574-2580.

Danner R. 1985. Vergleichende Untersuchungen zum konventionellen, organisch-biologischen und biologisch-dynamischen Weinbau. Thesis, Universität für Bodenkultur Wien, Wien.

de Ponti T, Rijk B and van Ittersum MK. 2012. The crop yield gap between organic and conventional agriculture. Agr Syst 108:1-9.

Delmas M, Doctori-Blass V and Shuster K. 2008. Ceago Vinegarden: How green is your wine? Environmental differentiation strategy through eco-labels. In American Association of Wine Economists. Cambridge University Press, UK.

Döring J, Frisch M, Tittmann S, Stoll M and Kauer R. 2015. Growth, yield and fruit quality of grapevines under organic and biodynamic management. PLoS ONE 10:e0138445.

Dupin I, Fischer U and Schlich P. 2000. Differentiation of wines produced by organic or conventional viticulture according to their sensory profiles and aroma composition. Am J Enol Vitic 51:299.

Duso C. 1989. Role of the predatory mites Amblyseius aberrans (Oud.), Typhlodromus pyri Scheuten and Amblyseius andersoni (Chant) (Acari, Phytoseiidae) in vineyards I. The effects of single or mixed phytoseiid population releases on spider mite densities (Acari, Tetranychidae). J Appl Entomol 107:474-492.

FAO. 1999. FAO position paper on Organic Agriculture. http://www. fao.org/docrep/meeting/X0075e.htm.

Fleury D and Fleury I. 2016. Evaluation des populations de coccinelles asiatiques en viticulture intégrée ou biologique. Revue Suisse Vitic Arboric Hortic 48:124-129.

Freitas NO, Yano-Melo AM, da Silva FSB, de Melo NF and Maia LC. 2011. Soil biochemistry and microbial activity in vineyards 
under conventional and organic management at Northeast Brazil. Sci Agric 68:223-229.

Fritz J, Athmann M, Meissner G, Kauer R and Köpke U. 2017. Quality characterisation via image forming methods differentiates grape juice produced from integrated, organic or biodynamic vineyards in the first year after conversion. Biol Agric Hortic 33:195-213.

Garaguso I and Nardini M. 2015. Polyphenols content, phenolics profile and antioxidant activity of organic red wines produced without sulfur dioxide/sulfites addition in comparison to conventional red wines. Food Chem 179:336-342.

Gehlen P, Neu J and Schröder D. 1988. Bodenchemische und bodenbiologische Vergleichsuntersuchungen konventionell und biologisch bewirtschafteter Weinstandorte an der Mosel. Wein-Wissen 43:161-173.

Giannakis C, Bucheli CS, Skene KGM, Robinson SP and Scott NS. 1998. Chitinase and $\beta$-1,3-glucanase in grapevine leaves: A possible defence against powdery mildew infection. Aust J Grape Wine Res 4:14-22.

Granato D, Koot A, Schnitzler E and van Ruth SM. 2015a. Authentication of geographical origin and crop system of grape juices by phenolic compounds and antioxidant activity using chemometrics. J Food Sci 80:584-593.

Granato D, Koot A and van Ruth SM. 2015b. Geographical provenancing of purple grape juices from different farming systems by proton transfer reaction mass spectrometry using supervised statistical techniques. J Sci Food Agric 95:2668-2677.

Granato D, Margraf T, Brotzakis I, Capuano E and van Ruth SM. $2015 \mathrm{c}$. Characterization of conventional, biodynamic, and organic purple grape juices by chemical markers, antioxidant capacity, and instrumental taste profile. J Food Sci 80:55-65.

Granato D, de Magalhães Carrapeiro M, Fogliano V and van Ruth SM. 2016. Effects of geographical origin, varietal and farming system on the chemical composition and functional properties of purple grape juices: A review. Trends Food Sci Tech 52:31-48.

Grime JP. 1973. Competitive exclusion in herbaceous vegetation. Nature 242:344-347.

Guesmi B, Serra T, Kallas Z and Gil Roig JM. 2012. The productive efficiency of organic farming: The case of grape sector in Catalonia. Span J Agric Res 10:552-566.

Guzzon R, Gugole S, Zanzotti R, Malacarne M, Larcher R, Von Wallbrunn C and Mescalchin E. 2016. Evaluation of the oenological suitability of grapes grown using biodynamic agriculture: The case of a bad vintage. J Appl Microbiol 120:355-365.

Hardie WJ and Considine JA. 1976. Response of grapes to water-deficit stress in particular stages of development. Am J Enol Vitic 27:55-61.

Hendgen M, Hoppe B, Döring J, Friedel M, Kauer R, Frisch M, Dahl A and Kellner H. 2018. Effects of different management regimes on microbial biodiversity in vineyard soils. Sci Rep 8:9393.

Henick-Kling T. 1995. Summary of effects of organic and conventional grape production practices on juice and wine composition. In 3rd Organic Grape and Wine Production Symposium. Pool RM (ed.), pp. 89-102.

Hofmann U. 1991. Untersuchungen über die Umstellungsphase auf ökologische Bewirtschaftungssysteme im Weinbau im Vergleich zur konventionellen Wirtschaftsweise am Beispiel MariannenaueErbach. Justus-Liebig-Universität Gießen.

Hole DG, Perkins AJ, Wilson JD, Alexander IH, Grice PV and Evans AD. 2005. Does organic farming benefit biodiversity? Biol Conserv 122:113-130.

Horn HS. 1975. Markovian properties of forest succession. In Ecology and Evolution of Communities. Cody ML and Diamond JM (eds.), pp. 196-211. Belkap Press, Massachusetts.

Huber $M$ et al. 2010. Standardization and validation of the visual evaluation of biocrystallizations. Biol Agric Hortic 27:25-40.
Ihaka R and Gentleman R. 1996. R: A Language for data analysis and graphics. J Comput Graph Stat 5:299-314.

Isaia $\mathrm{M}$, Bona $\mathrm{F}$ and Badino $\mathrm{G}$. 2006. Influence of landscape diversity and agricultural practices on spider assemblage in Italian vineyards of Langa Astigiana (Northwest Italy). Environ Entomol 35:297-307.

Kauer R. 1994. Vergleichende Untersuchungen zum integrierten und ökologischen Weinbau in den ersten drei Jahren der Umstellung: Ergebnisse von 12 Standorten im Anbaugebiet Rheinhessen bei den Rebsorten Müller-Thurgau und Riesling. Justus-Liebig-Universität Gießen.

Kavargiris SE, Mamolos AP, Tsatsarelis CA, Nikolaidou AE and Kalburtji KL. 2009. Energy resources' utilization in organic and conventional vineyards: Energy flow, greenhouse gas emissions and biofuel production. Biomass Bioenergy 33:1239-1250.

Kecskeméti E, Berkelmann-Löhnertz B and Reineke A. 2016. Are epiphytic microbial communities in the carposphere of ripening grape clusters (Vitis vinifera L.) different between conventional, organic, and biodynamic grapes? PLoS ONE 11:e0160852.

Kliewer WM and Dokoozlian NK. 2005. Leaf area/crop weight ratios of grapevines: Influence on fruit composition and wine quality. Am J Enol Vitic 56:170-181.

Köhler W, Schachtel G and Voleske P. 2007. Biostatistik. SpringerVerlag, Berlin.

Kucera A. 2017. Waadtländer Weinbau: Winzer schwören der Chemie ab. Neue Zürcher Zeitung, Zürich, Switzerland.

Laghi L, Versari A, Marcolini E and Parpinello GP. 2014. Metabolomic Investigation by $1 \mathrm{H}-\mathrm{NMR}$ to discriminate between red wines from organic and biodynamic grapes. Food Nutr Sci 5:52-59.

Lante A, Crapisi A, Lomolino G and Spettoli P. 2004. Chemical parameters, biologically active polyphenols and sensory characteristics of some Italian organic wines. J Wine Res 15:203-209.

Lee KE. 1985. Earthworms, Their Ecology and Relationships with Soils and Land Use. Academic Press, University of Michigan.

Leiber F, Fuchs N and Spiess H. 2006. Biodynamic agriculture today. In Organic Agriculture: A Global Perspective. Kristiansen P et al. (eds.), pp. 141-149. CSIRO Publishing, Collingwood, Victoria, Australia.

Lernoud J and Willer H. 2016. Organic agriculture worldwide: Current statistics. In The world of Organic Agriculture: Statistics \& Emerging Trends 2016. Willer H and Lernoud J (eds.), pp. 33-116. FiBL and IFOAM, Frick, Switzerland, and Bonn, Germany.

Linder C, Viret O, Spring J-L, Droz P and Dupuis D. 2006. Viticulture intégrée et bio-organique:synthèse de sept ans d'observations. Revue Suisse Vitic Arboric Hortic 38:235-243.

Mackie KA, Müller T, Zikeli S and Kandeler E. 2013. Long-term copper application in an organic vineyard modifies spatial distribution of soil micro-organisms. Soil Biol Biochem 65:245-253.

Mäder P, Fließbach A, Dubois D, Gunst L, Fried P and Niggli U. 2002. Soil fertility and biodiversity in organic farming. Science 296:1694-1697.

Magnin-Robert M, Trotel-Aziz P, Quantinet D, Biagianti S and Aziz A. 2007. Biological control of Botrytis cinerea by selected grapevineassociated bacteria and stimulation of chitinase and $\beta-1,3$ glucanase activities under field conditions. Europ J Plant Pathol 118:43-57.

Malusà E, Laurenti E, Ghibaudi E and Rolle L. 2004. Influence of organic and conventional management on yield and composition of grape cv. 'Grignolino'. Acta Hort 640:135-141.

Martin KR and Rasmussen KK. 2011. Comparison of sensory qualities of geographically paired organic and conventional red wines from the southwestern US with differing total polyphenol concentrations: A randomized pilot study. Food Nutr Sci 02:1150-1159.

Masson V and Masson P. 2013. Landwirtschaft, Garten- und Weinbau biodynamisch. AT Verlag, Aarau and Munich. 
Matthews MA and Anderson MM. 1989. Reproductive development in grape (Vitis vinifera L.): Responses to seasonal water deficits. Am J Enol Vitic 40:52-60.

Meißner G. 2015. Untersuchungen zu verschiedenen Bewirtschaftungssystemen im Weinbau unter besonderer Berücksichtigung der biologisch-dynamischen Wirtschaftsweise und des Einsatzes der biologisch-dynamischen Präparate. Justus-Liebig-Universität Gießen.

Micelli A, Negro C, Tommasi L and De Leo P. 2003. Polyphenols, resveratrol, antioxidant activity and ochratoxin a contamination in red table wines, controlled denomination of origin (DOC) wines and wines obtained from organic farming. J Wine Res 14:115-120.

Morrison-Whittle P, Lee SA and Goddard MR. 2017. Fungal communities are differentially affected by conventional and biodynamic agricultural management approaches in vineyard ecosystems. Agric Ecosys Environ 246:306-313.

Mulero J, Pardo F and Zafrilla P. 2009. Effect of principal polyphenolic components in relation to antioxidant activity in conventional and organic red wines during storage. Eur Food Res and Technol 229:807-812

Mulero J, Pardo F and Zafrilla P. 2010. Antioxidant activity and phenolic composition of organic and conventional grapes and wines. $\mathrm{J}$ Food Compos Anal 23:569-574.

Nascimbene J, Marini L and Paoletti MG. 2012. Organic farming benefits local plant diversity in vineyard farms located in intensive agricultural alndscapes. Environ Manage 49:1054-1060.

Neslen A. 2017. Glyphosate weedkiller, previously linked to cancer, judged safe by EU watchdog. The Guardian, London, UK.

Núñez-Delicado E, Sánchez-Ferrer A, García-Carmona FF and LópezNicolás JM. 2005. Effect of organic farming practices on the level of latent polyphenol oxidase in grapes. J Food Sci 70:C74-C78.

Okur N, Altindİşlİ A, Çengel M, Göçmez S and Kayikçioğlu HH. 2009. Microbial biomass and enzyme activity in vineyard soils under organic and conventional farming systems. Turk J Agric For 33:413-423

Oliva J, Garde-Cerdán T, Martínez-Gil AM, Salinas MR and Barba A. 2011. Fungicide effects on ammonium and amino acids of Monastrell grapes. Food Chem 129:1676-1680.

Organic Industry Standards and Certification Committee (OISCC). 2015. Department of Agriculture and Water Resources. Australian National Standard for Organic and Bio-Dynamic Produce. Accessed 18 April 2017.

Otreba JB, Berghofer E, Wendelin S and Eder R. 2006. Polyphenols anti-oxidative capacity in Austrian wines from conventional and organic grape production. Mitt Klosterneuburg 56:22-32.

Pancher M, Coel M, Corneo PE, Longa CMO, Yousaf S, Pertot I and Campisano A. 2012. Fungal endophytic communities in grapevines (Vitis vinifera L.) respond to crop management. Appl Environ Microb 78:4308-4317.

Paoletti MG, Sommaggio D, Favretto MR, Petruzzelli G, Pezzarossa B and Barbafieri M. 1998. Earthworms as useful bioindicators of agroecosystem sustainability in orchards and vineyards with different inputs. Applied Soil Ecol 10:137-150.

Parpinello GP, Rombolà AD, Simoni M and Versari A. 2015. Chemical and sensory characterization of Sangiovese red wines: Comparison between biodynamic and organic management. Food Chem 167:145-152.

Patrignani F et al. 2017. Characterization of yeast microbiota, chemical and sensory properties of organic and biodynamic Sangiovese red wines. Ann Microbiol 67:99-109.

Peverieri GS, Simoni S, Goggioli D, Liguori M and Castagnoli M. 2009. Effects of variety and management practices on mite species diversity in Italian vineyards. B Insectol 62:53-60.
Picone G, Trimigno A, Tessarin P, Donnini S, Rombolà AD and Capozzi F. 2016. ${ }^{1} \mathrm{H}$ NMR foodomics reveals that the biodynamic and the organic cultivation managements produce different grape berries (Vitis vinifera L. cv. Sangiovese). Food Chem 213:187-195.

Pike BPA. 2015. Effect of organic, biodynamic and conventional vineyard management inputs on grapevine growth and susceptibility to powdery mildew and Botrytis bunch rot. Thesis, School of Agriculture, Food and Wine. The University of Adelaide.

Pool RM and Robinson JA. 1995. The SARE - Cornell organic grape project. In 3rd Organic Grape and Wine Production Symposium. Pool RM (ed.), pp. 7-14.

Probst B, Schüler C and Joergensen RG. 2008. Vineyard soils under organic and conventional management-microbial biomass and activity indices and their relation to soil chemical properties. Biol Fert Soils 44:443-450.

Provenzano MR, El Bilali H, Simeone V, Baser N, Mondelli D and Cesari G. 2010. Copper contents in grapes and wines from a Mediterranean organic vineyard. Food Chem 122:1338-1343.

Provost C and Pedneault K. 2016. The organic vineyard as a balanced ecosystem: Improved organic grape management and impacts on wine quality. Sci Hortic 208:43-56.

Puig-Montserrat X, Stefanescu C, Torre I, Palet J, Fàbregas E, Dantart J, Arrizabalaga A and Flaquer C. 2017. Effects of organic and conventional crop management on vineyard biodiversity. Agr Ecosyst Environ 243:19-26.

Radić T, Likar M, Hančević K, Bogdanović I and Pasković I. 2014. Occurrence of root endophytic fungi in organic versus conventional vineyards on the Croatian coast. Agr Ecosyst Environ 192:115-121.

Reeve JR, Carpenter-Boggs L, Reganold JP, York AL, Mcgourty G and McCloskey LP. 2005. Soil and winegrape quality in biodynamically and organically managed vineyards. Am J Enol Vitic 56:367-376.

Regulation (EC) No. 834/2007.

Regulation (EC) No. 889/2008.

Regulation (EU) No. 203/12.

Reinecke AJ, Albertus RMC, Reinecke SA and Larink O. 2008. The effects of organic and conventional management practices on feeding activity of soil organisms in vineyards. Afr Zool 43:66-74.

Reuveni M, Zahavi T and Cohen Y. 2001. Controlling downy mildew (Plasmopara viticola) in field-grown grapevine with $\beta$-aminobutyric acid (BABA). Phytoparasitica 29:125-133.

Rodrigues AD et al. 2012. Neuroprotective and anticonvulsant effects of organic and conventional purple grape juices on seizures in Wistar rats induced by pentylenetetrazole. Neurochem Int 60:799-805.

Ross CF, Weller KM, Blue RB and Reganold JP. 2009. Difference testing of Merlot produced from biodynamically and organically grown wine grapes. J Wine Res 20:85-94.

Santiago I. 2010. Biodynamic vs. conventional viticulture in Australia: A comparison of costs and operations. Faculty of Sciences, School of Agriculture, Food and Wine. University of Adelaide.

Santiago I and Johnston L. 2011. Comparing the costs of biodynamic and conventional viticulture in Australia: A recent study. Wine \& Vit J 26:61-64.

Schmid F, Moser G, Müller H and Berg G. 2011. Functional and structural microbial diversity in organic and conventional viticulture: Organic farming benefits natural biocontrol agents. Appl Environ Microb 77:2188-2191.

Stanhill G. 1990. The comparative productivity of organic agriculture. Agr Ecosyst Environ 30:1-26.

Steindl A, Strumpf T and Riepert F. 2011. Bioverfügbare Kupfergehalte in ökologisch und konventionell bewirtschafteten Böden deutscher 
Wein- und Hopfenanbaugebiete. Teil 3: Bestimmung des pflanzenverfügbaren Anteils Kupfer- und anderer Schwermetallgehalte durch NH4NO3-Extraktion. Journal für Kulturpflanzen 63:156-166.

Steiner R. 2005. Geisteswissenschaftliche Grundlagen zum Gedeihen der Landwirtschaft. Rudolf Steiner Verlag, Dornach.

Stinner DH. 2007. The science of organic farming. In Organic Farming: An International History. Lockeretz W (ed.), pp. 40-72. CAB International, Wallingford, OX, UK.

Stoll M, Loveys B and Dry P. 2000. Hormonal changes induced by partial rootzone drying of irrigated grapevines. J Exp Bot 51:1627-1634.

Strumpf T, Stendel U and Vetter C. 2009. Gesamtgehalte von Kupfer in Böden des Kernobstanbaus, Weinbergen und Hopfenanlagen. Journal für Kulturpflanzen 61:117-125.

Strumpf T, Steindl A, Strassemeyer J and Riepert F. 2011. Erhebung von Kupfergesamtgehalten in ökologisch und konventionell bewirtschafteten Böden. Teil 1: Gesamtgehalte in Weinbergsböden deutscher Qualitätsanbaugebiete. Journal für Kulturpflanzen 63:131-143.

Tassoni A, Tango N and Ferri M. 2013. Comparison of biogenic amine and polyphenol profiles of grape berries and wines obtained following conventional, organic and biodynamic agricultural and oenological practices. Food Chem 139:405-413.

Tassoni A, Tango N and Ferri M. 2014. Polyphenol and biogenic amine profiles of Albana and Lambrusco grape berries and wines obtained following different agricultural and oenological practices. Food Nutr Sci 5:8-16.

Tinttunen S and Lehtonen P. 2001. Distinguishing organic wines from normal wines on the basis of concentrations of phenolic compounds and spectral data. Eur Food Res Technol 212:390-394.

Tobolková B, Polovka M, Belajová E, Korenovská M and Suhaj M. 2014. Possibilities of organic and conventional wines differentiation on the basis of multivariate analysis of their characteristics (EPR, UV-Vis, HPLC and AAS study). Eur Food Res Technol 239:441-451.

Tramontini S, Döring J, Vitali M, Ferrandino A, Stoll M and Lovisolo C. 2014. Soil water-holding capacity mediates hydraulic and hormonal signals of near-isohydric and near-anisohydric Vitis cultivars in potted grapevines. Funct Plant Biol 41:1119-1128.

UNI 11233-2009 European standard. Ente Nazionale Italiano di Unificazione. 2009.

USDA. National List. Accessed 18 April 2017.

USDA. Organic Regulations. Accessed 18 April 2017.

Vidal J and Kelly A. 2013. Bhutan set to plough lone furrow as world's first wholly organic country. The Guardian, London, UK.
Villanueva-Rey P, Vázquez-Rowe I, Moreira MT and Feijoo G. 2014. Comparative life cycle assessment in the wine sector: Biodynamic vs. conventional viticulture activities in NW Spain. J Clean Prod 65:330-341.

Vogt G. 2000. Entstehung und Entwicklung des ökologischen Landbaus im deutschsprachigen Raum. Stiftung Ökologie \& Landbau, Bad Dürkheim, Germany.

Vogt G. 2007. The origins of organic farming. In Organic Farming: An International History. Lockeretz W (ed.), pp. 9-29. CAB International, Wallingford, Oxford, UK.

Vrček IV, Bojić M, Žuntar I, Mendaš G and Medić-Šarić M. 2011. Phenol content, antioxidant activity and metal composition of Croatian wines deriving from organically and conventionally grown grapes. Food Chem 124:354-361.

Wheeler SA. 2006. The adoption and diffusion of organic agriculture: Economics, drivers and constraints. Centre for regulation and market analysis, school of commerce. University of South Australia, p. 342.

Wheeler SA and Crisp P. 2011. Going organic in viticulture: A casestudy comparison in Clare Valley, South Australia. Australas J Env Man 18:182-198.

White GB. 1995. The economics of growing grapes organically. In 3rd Organic Grape and Wine Production Symposium. Pool RM (ed.), pp. 76-85.

Wysling A. 2015. Biolandwirtschaft in Südtirol: Ein Dorf kämpft gegen die Agrochemie. Neue Zürcher Zeitung, Zürich, Switzerland.

Yang S and Tyree MT. 1992. A theoretical model of hydraulic conductivity recovery from embolism with comparison to experimental data on Acer saccharum. Plant Cell Environ 15:633-643.

Yildirim HK, Akçay YD, Güvenç U and Sözmen EY. 2004. Protection capacity against low-density lipoprotein oxidation and antioxidant potential of some organic and non-organic wines. Int J Food Sci Nutr 55:351-362.

Yildirim HK, Üren A and Yücel U. 2007. Evaluation of biogenic amines in organic and non-organic wines by HPLC OPA derivatization. Food Technol Biotech 45:62-68.

Yiridoe E, Bonti-Ankomah S and Martin R. 2005. Comparison of consumer perceptions and preference toward organic versus conventionally produced foods: A review and update of the literature. Renew Agr Food Syst 20:193-205.

Zalecka A, Kahl J, Doesburg P, Pyskow B, Huber M, Skjerbaek K and Ploeger A. 2010. Standardization of the Steigbild method. Biol Agric Hortic 27:41-57. 